\title{
Effects of Addition Rate and Acid Matrix on the Destruction of Ammonium by the Semi-continuous Addition of Sodium Nitrite during Evaporation
}

\author{
Edward A. Kyser
}

August 2007

\author{
Washington Savannah River Company \\ Savannah River Site \\ Aiken, SC 29808
}

Prepared for the U. S. Department of Energy under contract DE-AC09-96SR18500. 



\title{
Effects of Addition Rate and Acid Matrix on the \\ Destruction of Ammonium by the Semi-continuous Addition of Sodium Nitrite during Evaporation
}

\author{
Edward A. Kyser
}

August 27, 2007

\begin{abstract}
Author
Original signed by E. A. Kyser on 8/27/2007

E. A. Kyser

Date
\end{abstract}

Technical Reviewers

Original signed by M. C. Thompson on 8-21-2007

Major Thompson

Date

Original signed by J. E. Laurinat on 8-21-2007

J. E. Laurinat (Calculations only)

Date

Customer Concurrence

Original approved per email by R. L. Huffines on 8/29/2007

R. L. Huffines

Date

\section{Management Approval}

Original signed by S. D. Fink on 8/31/2007

S. D. Fink

Date 


\section{Table of Contents:}

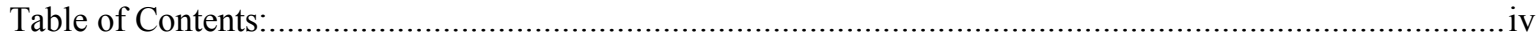

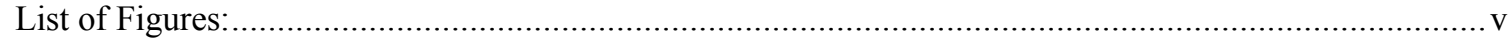

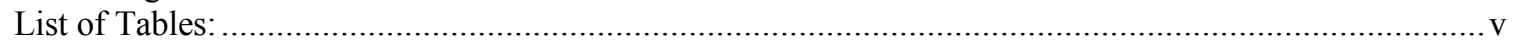

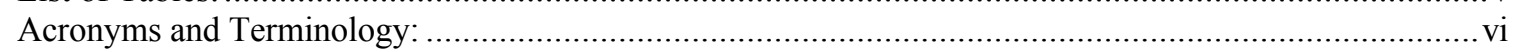

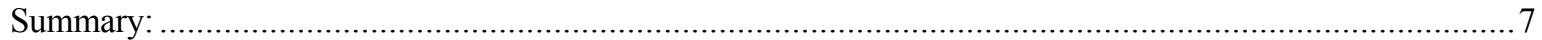

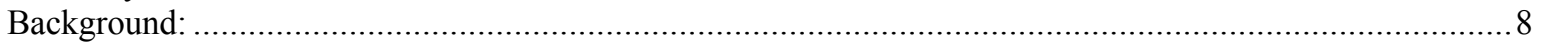

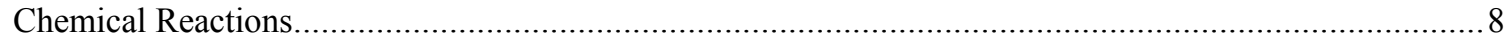

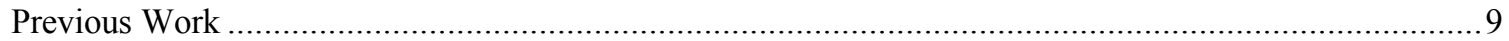

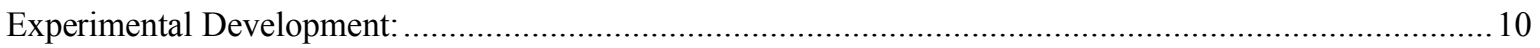

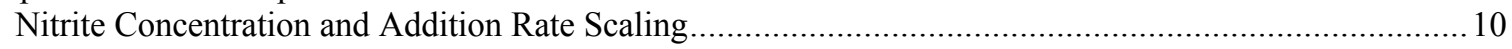

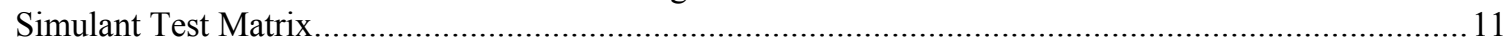

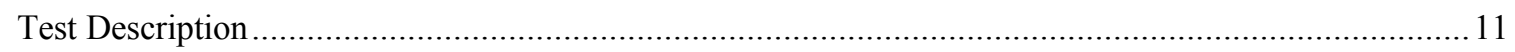

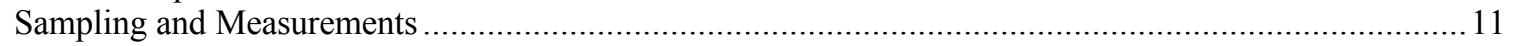

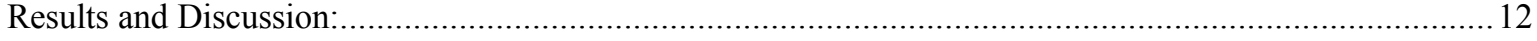

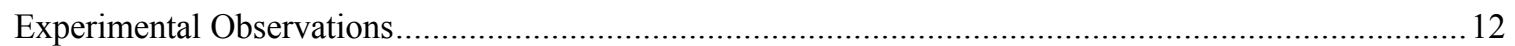

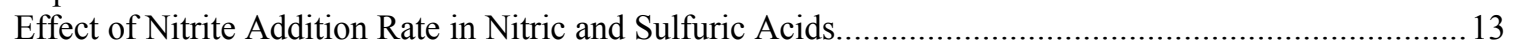

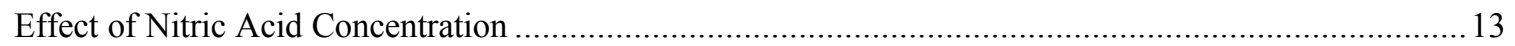

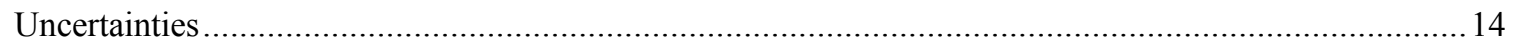

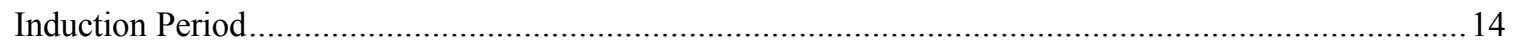

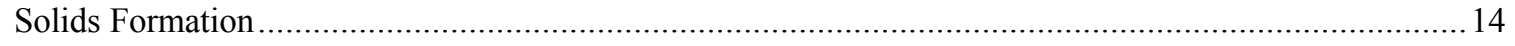

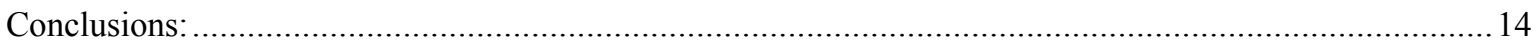

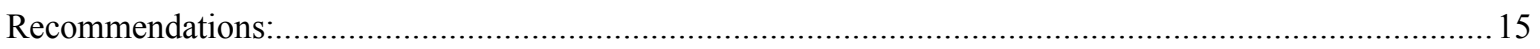

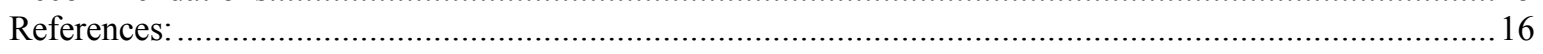

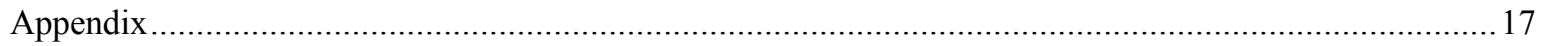




\section{List of Figures:}

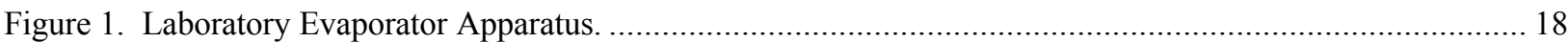

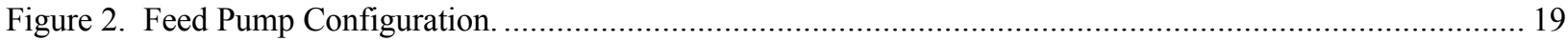

Figure 3. Reaction Vessel Showing $\mathrm{NO}_{2}$ and $\mathrm{N}_{2}$ Off-gas for $\mathrm{HNO}_{3}$ and $\mathrm{H}_{2} \mathrm{SO}_{4}$ Systems................................. 20

Figure 4. Effect of Nitrite Addition Rate on Ammonium Destruction vs. Quantity of Nitrite Added (molar

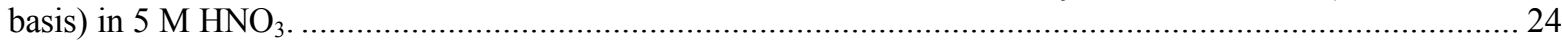

Figure 5. Effect of Nitrite Addition Rate on Ammonium Destruction vs. Quantity of Nitrite Added (molar

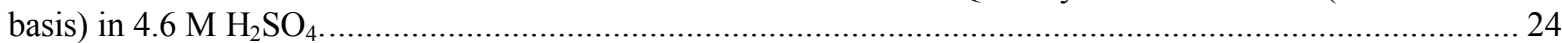

Figure 6. Effect of $\mathrm{HNO}_{3}$ Concentration on Ammonium Destruction vs. Quantity of Nitrite Added (molar

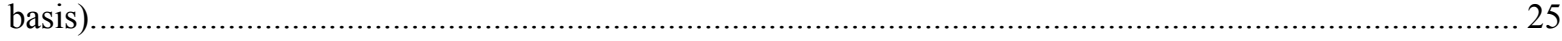

Figure 7. Effect of Nitrite Addition Rate on Cumulative Ammonium Destruction Efficiency in $5 \mathrm{M} \mathrm{HNO}_{3} \ldots \ldots \ldots . . .26$

Figure 8. Effect of Nitrite Addition Rate on Cumulative Ammonium Destruction Efficiency in 4.6 M

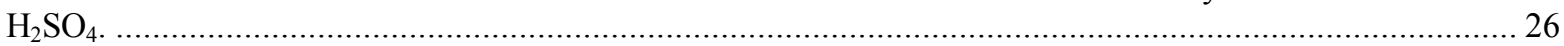

Figure 9. Effect of $\mathrm{HNO}_{3}$ Concentration Addition Rate on Cumulative Ammonium Destruction Efficiency.......... 27

\section{List of Tables:}

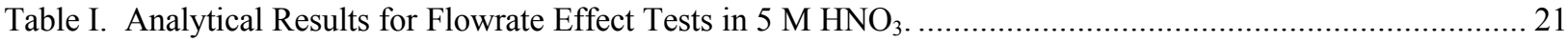

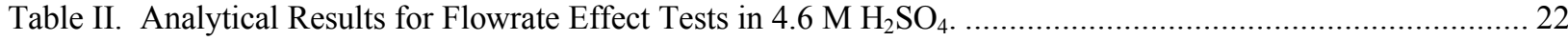

Table III. Analytical Results for $\mathrm{HNO}_{3}$ Concentration Effect Tests............................................................... 23

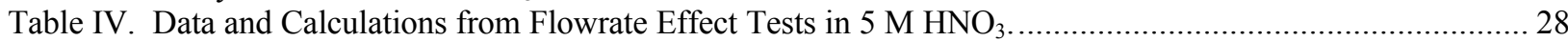

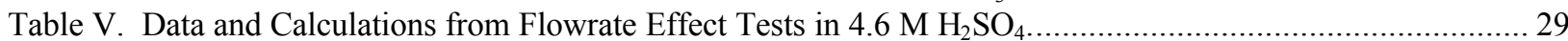

Table VI. Data and Calculations from for $\mathrm{HNO}_{3}$ Concentration Effect Tests............................................... 30

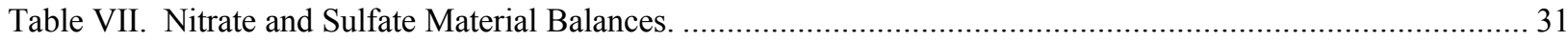


Acronyms and Terminology:

$\mathrm{AD}$ - Analytical Development Department

Diluent water - Water added to an operating evaporator to keep the volume constant.

Efficiency - Calculated value equal to the moles ammonium consumed per mole of nitrite added

IC - Ion Chromatography

HAW - High Activity Waste

HLW - (High Level Waste) Liquid waste containing actinides that will be transferred to the tank farm

$\mathrm{HNO}_{2}-$ Nitrous acid

$\mathrm{HNO}_{3}-$ Nitric acid

LAW - Low Activity Waste

LIMS - Laboratory Information Management System

$\mathrm{N}_{2} \mathrm{O}$ - Nitrous oxide

$\mathrm{N}_{2} \mathrm{O}_{3}$ - Dinitrogen Trioxide

$\mathrm{N}_{2} \mathrm{O}_{4}$ - Dinitrogen Tetroxide

$\mathrm{NaNO}_{2}-$ Sodium nitrite

$\mathrm{NH}_{4}-$ Ammonium ion

$\mathrm{NO}$ - Nitric oxide

$\mathrm{NO}_{2}$ - Nitrogen dioxide

$\mathrm{NO}_{2}^{-}, \mathrm{NO}_{3}^{-}-$Nitrite ion, Nitrate ion

$\mathrm{NO}_{\mathrm{x}}$ - Mixture of Nitric oxide and Nitrogen dioxide

$\mathrm{SO}_{4}{ }^{2-}$ - Sulfate ion: Reaction product from sulfamate in the ferrous sulfamate 


\title{
Effects of Addition Rate and Acid Matrix on the Destruction of Ammonium by the Semi-continuous Addition of Sodium Nitrite during Evaporation
}

\author{
By \\ Edward A. Kyser \\ Savannah River National Laboratory \\ Actinide \& Chemical Technology Section
}

August 2007

\begin{abstract}
Summary:
The destruction of ammonium by the semi-continuous addition of sodium nitrite during acidic evaporation can be achieved with a wide range of waste compositions. The efficiency of nitrite utilization for ammonium destruction was observed to vary from less than $20 \%$ to $60 \%$ depending on operating conditions. The effects of nitric acid concentration and nitrite addition rate are dominant factors that affect the efficiency of nitrite utilization for ammonium destruction. Reducing the acid concentration by performing acid recovery via steam stripping prior to performing nitrite destruction of ammonium will require more nitrite due to the low destruction efficiency. The scale-up of the baseline rate nitrite addition rate from the $100 \mathrm{~mL}$ to the 1600 gallon batch size has significant uncertainty and poses the risk of lower efficiency at the plant scale. Experience with plant scale processing will improve confidence in the application of nitrite destruction of ammonium to different waste streams.
\end{abstract}




\section{Background:}

After evaporation, Low Activity Waste (LAW) and High Activity Waste (HAW) solutions require $\mathrm{pH}$ adjustment with caustic (i.e., $50 \mathrm{wt} \%$ sodium hydroxide) prior to transfer to the Tank Farm. During this adjustment any ammonium present in these solutions is converted to ammonia. Ammonia in alkaline solution is volatile and poses both a flammability risk in air and issues with the production of ammonium nitrate if the fumes combine with nitric acid vapors in the ventilation system. As a result, $\mathrm{H}$ Canyon restricts the discard of ammonia-bearing solutions to the Tank Farm and implements Safety Significant controls for the neutralization of ammonium bearing solutions to minimize accumulation of ammonium nitrate on the Process Vessel Vent (PVV) filters in the canyon ventilation systems.

Kyser $^{1}$ previously investigated the semi-continuous treatment of the raffinate from the Neptunium oxidizing flowsheet with sodium nitrite to destroy the ammonium present. The basis for that flowsheet is a report by Wallace ${ }^{2}$ that discussed laboratory work where nitric oxide $\left(\mathrm{NO}_{(\mathrm{g})}\right)$ was added to hot nitric acid solution. In Wallace's work, the nitric oxide is almost immediately converted to nitrous acid $\left(\mathrm{HNO}_{2}\right)$ and nitrogen dioxide $\left(\mathrm{NO}_{2}\right)$ and the nitrous acid reacts with the ammonium ion to produce nitrogen gas and water. When sodium nitrite solution was used instead of nitric oxide gas, similar reactions occurred.

The addition rate of the sodium nitrite must be controlled to avoid rapid off-gassing which could exceed the capacity of the off-gas system. Formic acid denitration ${ }^{3}$ was used as a model as much of the chemistry is very similar. H-Canyon Engineering previously estimated that as much as 100 SCFM of non-condensable gases could be vented from the standard evaporator design based on formic acid denitration work performed in F-Canyon. Laurinat ${ }^{4}$ calculated a nitrite addition rate of 60 moles of nitrite per minute would produce a maximum non-condensable off-gas rate of $100 \mathrm{scfm}$.

The previous work by Kyser ${ }^{1}$ addressed ammonium destruction in one specific high ammonium waste stream (i.e. Neptunium oxidizing flowsheet waste). H-Canyon Engineering requested additional work to provide a basis for extending this treatment to both HAW and LAW waste streams. After discussion, SRNL and Engineering personnel decided to focus on the effect of nitric acid concentration, nitrite addition rate and the difference between nitric and sulfuric acid systems.

\section{Chemical Reactions}

The chemical reactions listed below occur to a varying degree when nitric oxide $\left(\mathrm{NO}_{(\mathrm{g})}\right)$ or sodium nitrite $\left(\mathrm{NaNO}_{2}\right)$ is added to acidic ammonium $\left(\mathrm{NH}_{4}{ }^{+}\right)$solutions. The kinetics of ammonium reaction with nitrous acid was initially studied by Dusenbury ${ }^{5}$. Temperature and concentrations will affect the competition between the various reactions. Based on previous scoping tests, it appears that reactions 3, 4, and 5 are competing for the limited amount of nitrous acid $\left(\mathrm{HNO}_{2}\right)$ present during continuous nitrite addition to nitric acid solution. In the temperature range of 90 to $115^{\circ} \mathrm{C}$, a significant fraction of the nitrite reacts with ammonium (reaction 3 ) but at ambient temperature the other reactions predominate. 
(1) $\mathrm{NaNO}_{2} \leftrightarrow \mathrm{Na}^{+}+\mathrm{NO}_{2}{ }^{-}$

(2) $\mathrm{NO}_{2}{ }^{-}+\mathrm{H}^{+} \leftrightarrow \mathrm{HNO}_{2}$

(3) $\mathrm{HNO}_{2}+\mathrm{NH}_{4}^{+} \rightarrow \mathrm{N}_{2(g)}+2 \mathrm{H}_{2} \mathrm{O}+\mathrm{H}^{+}$

(4) $2 \mathrm{HNO}_{2} \rightarrow \mathrm{NO}+\mathrm{NO}_{2}(g)+\mathrm{H}_{2} \mathrm{O}$

(5) $\mathrm{HNO}_{2}+\mathrm{HNO}_{3} \leftrightarrow 2 \mathrm{NO}_{2}(\mathrm{~g})+\mathrm{H}_{2} \mathrm{O}$

(6) $2 \mathrm{NO}+\mathrm{HNO}_{3}+\mathrm{H}_{2} \mathrm{O} \leftrightarrow 3 \mathrm{HNO}_{2}$

(7) $\mathrm{NO}(\mathrm{g})+1 / 2 \mathrm{O}_{2(g)} \leftrightarrow \mathrm{NO}_{2}(\mathrm{~g})$

(8) $3 \mathrm{NO}_{(\mathrm{g})} \leftrightarrow \mathrm{N}_{2} \mathrm{O}_{(\mathrm{g})}+\mathrm{NO}_{2}(\mathrm{~g})$

(9) $2 \mathrm{NO}_{2}(\mathrm{~g}) \leftrightarrow \mathrm{N}_{2} \mathrm{O}_{4}(\mathrm{~g})$

(9) $\mathrm{NO}_{(\mathrm{g})}+\mathrm{NO}_{2}(\mathrm{~g}) \leftrightarrow \mathrm{N}_{2} \mathrm{O}_{3}(\mathrm{~g})$

\section{Previous Work}

H-Canyon Engineering had considered the batch-wise addition of nitrite to the feed solution for an ammonium destruction flowsheet. Laboratory tests showed that during batch addition of nitrite to $5 \mathrm{M} \mathrm{HNO}_{3}$, the nitrite was consumed by side reactions with $\mathrm{HNO}_{3}$ without reacting appreciably with the ammonium. Nitrite added to a stirred beaker of $5 \mathrm{M} \mathrm{HNO}_{3}$ was observed to dissipate from $0.28 \mathrm{M}$ to $<0.002 \mathrm{M}$ within eight hours of addition. (The half-life of nitrite in this solution was $\sim 1$ hour.) When nitrite was added to a stirred beaker of $5 \mathrm{M} \mathrm{HNO}_{3}$ at ambient temperature followed by heating of the solution to $90{ }^{\circ} \mathrm{C}$, the nitrite was completely destroyed prior to the solution reaching the reaction temperature (typically no more than 15-20 minutes). Batch tests with as much as eight moles of nitrite per mole of ammonium destroyed no more than $30 \%$ of the ammonium during the addition and heat-up of $5 \mathrm{M} \mathrm{HNO}_{3}$ solution to $90^{\circ} \mathrm{C}$. Based on these test results the H-Canyon customer accepted that batch addition of nitrite to the evaporator feed tank would never provide the desired destruction efficiency and that approach was abandoned.

Testing of the semi-continuous addition of nitrite solution to hot evaporator solutions generally yielded a significant (i.e., 30-40\%) ammonium destruction efficiency at $95{ }^{\circ} \mathrm{C}$. At temperatures of $105{ }^{\circ} \mathrm{C}$ and above, similar ammonium destruction efficiencies were observed however the efficiency appeared to increase near the end of the nitrite addition. Regardless of temperature, the reaction appeared to be pseudo zeroth order in ammonium concentration (i.e., the reaction rate appeared to be independent of the concentration of ammonium). Previously Dusenbury ${ }^{5}$ reported this reaction to be first order in ammonium concentration but that testing was performed at $\mathrm{pH} 2.8$ rather than the multi-molar nitric acid conditions of current interest. Kyser ${ }^{1}$ hypothesized that the competing reactions for the nitrous acid at $5 \mathrm{M} \mathrm{HNO}_{3}$ limit the amount of reactant(s) available to oxidize ammonium to a such low concentration that the slow steady addition of sodium nitrite controls the ammonium destruction rate (i.e., nitrous acid formation becomes the rate limiting reaction). The slow addition of nitrite to the hot solution is crucial to the successful destruction of ammonium and the efficient usage of the nitrite. No evidence of any surge in off-gas volume or foaming was observed during any of the previous tests although those tests were not continuously observed and neither the off-gas rate nor the volume was measured. 
Tests with actual Neptunium oxidizing flowsheet solutions demonstrated the successful destruction of greater than $95 \%$ of the ammonium by the addition of up to four moles of nitrite for each mole of ammonium to a near-boiling laboratory evaporator. An ammonium destruction efficiency (i.e. nitrite utilization) of 40 to 45 percent was observed in those tests. That efficiency was somewhat higher than the expected efficiency of 25 to 40 percent previously observed in the tests with surrogate solutions. The proposed flowsheet called for the subsurface addition of an $18.4 \mathrm{wt} \%(3 \mathrm{M})$ sodium nitrite solution to the near-boiling evaporator at a controlled rate to limit the off-gas rate to $100 \mathrm{scfm}$.

The current study is an extension of the previous work on the Neptunium oxidizing flowsheet waste stream. Essentially the same equipment was used as was used for the semi-continuous work of the previous study. The equipment was setup to perform semicontinuous addition of nitrite to a hot batch of surrogate solution (100 mL scale) in a glass laboratory evaporator (boiling flask and water cooled condenser). Tests were performed with this equipment at $95^{\circ} \mathrm{C}$ with magnetic stirring at $100 \mathrm{rpm}$ at near total reflux. The evaporator equipment is shown in Figure 1 and the nitrite feed pump is shown in Figure 2.

\section{Experimental Development:}

\section{Nitrite Concentration and Addition Rate Scaling}

The plant process equipment has a limitation on the total non-condensable off-gas rate that the system can accommodate. That constraint limits the process addition rate to $60 \mathrm{moles} / \mathrm{min}$ of sodium nitrite ${ }^{4}$. In addition, H-Canyon Engineering proposed to constrain the addition of nitrite solution to maintain a relatively constant level in the evaporator: i.e., the diluent water (in the nitrite solution) addition rate will be matched to the steam boil-up control range for the evaporator. (Note: the plant evaporator operates as a partial, rather than total, reflux unit.) H-Canyon Engineering proposed to adjust the nitrite solution concentration to satisfy the above two constraints. Using the maximum operating volume (48" liquid depth or $\sim 1600$ gal/6000 L) and the above constraints, HCanyon Engineering proposed feeding a $3 \mathrm{M}(18.4 \mathrm{wt} \%)$ sodium nitrite solution at a maximum of $5 \mathrm{gal} / \mathrm{min}$ to destroy ammonium. The nitrite solution will be added subsurface, near the bottom of the evaporator pot.

These conditions were used as a target for designing the experimental condit ions. Scaling the solution addition $(5 \mathrm{gpm})$ to the pot volume (1600 gal) results in a target nitrite addition rate of $0.31 \mathrm{vol} \% / \mathrm{min}$. This scaling provides a baseline target for the laboratory nitrite addition rate of $0.31 \mathrm{~mL} / \mathrm{min}$ for the laboratory evaporator pot scale of $100 \mathrm{~mL}$. The addition of nitrite was measured by the depletion of the stock nitrite bottle from periodic mass measurement and measurement of the density of the nitrite stock solution.

The nitrite solution concentration for the current work was fixed at $18.4 \mathrm{wt} \%$ ( $3 \mathrm{M}$ $\mathrm{NaNO}_{2}$ ) based on the previous work. The nitrite addition rate was targeted for three distinct rates: $0.05,0.31$ and $1.6 \mathrm{~mL} / \mathrm{min}$ (or $0.15,0.93$ and $4.8 \mathrm{mmol} / \mathrm{min}$ ). Lower nitrite 
concentrations and lower flow-rates were previously observed to increase nitrite utilization.

\section{Simulant Test Matrix}

The simplified simulant test matrix of $5 \mathrm{M}$ acid (either nitric or sulfuric) with $0.25 \mathrm{M}$ ammonium sulfate was used for tests where the nitrite addition rate was varied. The sulfuric acid tests were planned to isolate the effect of the competing nitrate side reactions from the ammonium destruction reactions. The effect of nitric acid concentration was tested at 2,5 , and $8 \mathrm{M} \mathrm{HNO}_{3}$ with $0.25 \mathrm{M}$ ammonium sulfate with the base nitrite addition rate of $0.31 \mathrm{~mL} / \mathrm{min}$ of $3 \mathrm{M} \mathrm{HNO}_{2}$.

\section{Test Description}

The typical test was performed under the following conditions. The $18.4 \mathrm{wt} \%(3 \mathrm{M})$ sodium nitrite (prepared by mass with the actual concentration confirmed by Ion Chromatography (IC) anion analysis) was fed at the planned rate. (The actual rate was measured by mass depletion.) The solution was heated by a Super-Nuova ${ }^{\mathrm{TM}}$ stirring hotplate and the temperature measured with a type K thermocouple. The accuracy of this probe and display was cross-checked by boiling distilled water in the apparatus and a temperature of $100{ }^{\circ} \mathrm{C}$ observed. The solution was heated to near-boiling $\left(\sim 95^{\circ} \mathrm{C}\right)$. The evaporator apparatus consisted of a solution-temperature controlling hotplate, a four-port boiling flask and a water condenser. One large port was used for the condenser; one small port was used for the nitrite addition tube, one small port was used for the thermocouple probe and the last small port was used for sampling. When not in use, the sampling port was plugged. A peristaltic pump controlled the nitrite addition rate. A low flowrate of water cooled the condenser and condensed most of the water and nitric acid vapors. The evaporator operated in a near-total reflux mode (i.e., the condensate was returned to the boiling pot of the evaporator). A photo of the apparatus is shown as Figure 1.

\section{Sampling and Measurements}

Samples of the solution matrix in the evaporator pot were taken at the beginning and end of each test and periodically during the testing. A time for additional reaction at temperature was allowed after nitrite addition was completed prior to de-energizing the hot-plate. The nitrite pump was stopped and the amount of nitrite added determined by difference in weight of the nitrite addition bottle at each sampling point. In this manner, the amount of solution in the evaporator pot could be estimated within a few percent throughout the test. Density was determined by the use of a Parr Model 35M handheld density meter cross-checked with distilled water solution. The density of starting and ending evaporator solutions and the nitrite stock solution was measured. Since samples were at ambient temperature prior to measurement of ammonium and anions, no temperature correction of the density was necessary. The amount of water lost through the condenser was calculated from a material balance around the evaporator. Success of the ammonium destruction was judged solely on the ammonium material balance calculated from the results of ammonium analytical determination, the calculated mass of solution in the evaporator pot and the measured or estimated density of the solution at the time of sampling. The uncertainty in the total solution material balance increases over 
time as the evaporation progresses due to uncorrected evaporation losses and unmeasured changes in density. These uncertainties become minor as the relative amount of unreacted ammonium becomes small. Other analytical results such as those that show the nitrite, nitrate and sulfate levels are not required for the determination of successful ammonium destruction, but provide insight to the reactions that occurred.

\section{Results and Discussion:}

\section{Experimental Observations}

During the addition of nitrite, the solution gently boiled and small bubbles of gas evolved from the solution. The apparatus filled with brown fumes $\left(\mathrm{NO}_{2}\right.$ gases $)$ until the brown fumes emerged from the top of the condenser. There were three distinct types of bubbling: the boiling bubbles from the bottom of the flask, larger bubbles of gas near the end of the addition nozzle and very small bubbles of gas from a large region of the solution. The very small bubbles were likely from reaction of the nitrous acid that had been mixed throughout the solution. The larger bubbles near the nozzle appeared due to reaction in the high nitrite concentration zone. The bubbles from the bottom of the flask appeared to be due to boiling at nucleation sites on the glass bottom or on the boiling stones. Large bubbles from boiling were not a significant factor for tests at $95{ }^{\circ} \mathrm{C}$. The flask was not wrapped with fiberglass insulation as was done in some of the past testing. There was no evidence of any significant foaming of the solution in any of these experiments. Figure 3 shows a side-by-side comparison of the appearance of the nitric acid system during Test HAW-22c compared to the sulfuric acid system during Test HAW-22f.

The addition of nitrite at rates that exceed the basis for the molar addition rate could exceed the off-gas capability of the PVV system on the evaporator. None of the laboratory tests (scoping tests included) showed any problems with significant foaming or reactivity that suggests a change in chemistry. Many of the previous tests were performed at a nitrite addition rate of 0.6 to $0.7 \mathrm{vol} \% / \mathrm{min}$. Some of the current tests added nitrite at 1 to $2.8 \mathrm{vol} \% / \mathrm{min}$ and still showed no evidence of significant foaming. The upper flowrate limitation is strictly based on the off-gas capability of the equipment rather than any chemical or efficiency issue with the proposed process

The time, weight, density and ammonium data and results were all entered into a spreadsheet for each experiment. There is a set of test results for nitrite addition rate changes for the nitric acid system, another set for nitrite addition rate changes for the sulfuric acid system and a set for nitric acid concentration variation. The analytical data for each grouping of tests is included as Tables I, II, and III in the Appendix. The amount of nitrite added over time was calculated, material balances for total solution and ammonium were calculated and the efficiency of ammonium destruction at each sampling point determined. Calculated results follow as Tables IV (for the effect of nitrite addition rate into nitric acid), $\mathrm{V}$ (for the effect of nitrite addition rate into sulfuric acid and VI (for the effect of nitric acid concentration).

All indications are that there is no mechanism to "store" reaction potential from the nitrite addition. The half-life of nitrite in the solution was observed to only be about one hour at 
ambient temperature, so one can estimate that its half life in solution at $95{ }^{\circ} \mathrm{C}$ might be on the order of one minute or less (based on a doubling of the reaction rate per every $10^{\circ} \mathrm{C}$ increase in temperature). Any increase in ammonium destruction should somewhat reduce the amount of off-gas that must be vented since the ammonium reaction only generates one mole of gas per mole of nitrite reacted rather than the two moles of gas released when nitrite reacts with nitric acid. Increased efficiency for ammonium destruction should result in less $\mathrm{NO}_{2}$ release from the competing reactions and decrease the total amount of gas released.

\section{Effect of Nitrite Addition Rate in Nitric and Sulfuric Acids}

Figure 4 and Figure 7 show the effect of increasing nitrite addition rate on the destruction of ammonium in a $5 \mathrm{M} \mathrm{HNO}_{3}$ solution matrix. Figure 5 and Figure 8 show the effect of increasing nitrite addition rate on the destruction of ammonium in a $4.6 \mathrm{M} \mathrm{H}_{2} \mathrm{SO}_{4}$ solution matrix. As anticipated, high rates of nitrite addition evolved larger amounts of brown $\mathrm{NO}_{2}$ gases and the ammonium destruction efficiency dropped for both the nitric acid and sulfuric acid solution matrixes. The destruction efficiency was lower for the sulfuric acid system than for the nitric acid system under comparable conditions. It had been assumed that the lack of competition from the nitrate reactions would produce an increase in the ammonium destruction efficiency for the sulfuric acid tests, but the data show the opposite effect. Table VII is a compilation of the material balances for nitrate for selected tests. The nitrate analytical results show that 17 to $28 \pm 3 \%$ of the nitrite added was converted to nitrate for the sulfuric acid system tests (with low initial nitrate concentrations). In the nitrate acid solutions the analytical uncertainties are too large to discern how much nitrite is converted to nitrate. As anticipated, the addition of nitrite at slower rates improved the destruction efficiency.

The effect that nitrite addition rate has on the ammonium destruction efficiency combined with the scale-up uncertainty of this process from the $100 \mathrm{~mL}$ lab scale to the $6000 \mathrm{~L}$ plant scale suggests that a risk exists for low destruction efficiency. An ammonium destruction efficiency of as low as $25 \%$ was anticipated for the processing of the raffinate from the Neptunium oxidizing flowsheet but scale-up was acknowledged as a risk ${ }^{1}$. This investigation does nothing to reduce that risk. The current lack of experience with operating a nitrite addition flowsheet should be factored into processing plans for other solutions that contain ammonium until some plant-scale results are obtained.

\section{Effect of Nitric Acid Concentration}

The results of the tests at the baseline nitrite addition rate $(\sim 0.32 \mathrm{~mL} / \mathrm{min})$ for 2 to $8 \mathrm{M}$ $\mathrm{HNO}_{3}$ solutions are shown in Figure 6 and Figure 9. The overall destruction efficiency ranged from $30 \%$ at $2 \mathrm{M} \mathrm{HNO}_{3}$ to $60 \%$ at $8 \mathrm{M} \mathrm{HNO}_{3}$ with greater than 1.5 moles of nitrite added per mole of ammonium. In previous work, observations of some accelerated destruction of ammonium (surge) had been recognized but not understood ${ }^{1}$. The current work shows that the increasing nitrate concentration in the evaporator bottoms would cause changes in the destruction efficiency that explain the previously observed surge in destruction. The order of the reaction with respect to ammonium was concluded to be pseudo zeroth order with respect to ammonium concentration ${ }^{1}$ but a 
conclusion on the order of the reaction with respect to nitric acid concentration was not reached.

\section{Uncertainties}

Ammonium analytical uncertainties limit the accuracy of the material balance calculations for test conditions where less than $50 \%$ of the ammonium was destroyed. The ammonium analyses were performed by IC cation analysis and the standard stated error for ammonium by that method is $15 \% 1$-sigma. Mass measurements are assumed to have an uncertainty of $0.1 \%$. The uncertainties reflected by the error bars on all graphs are dominated by IC analytical uncertainty. The initial amount of ammonium present was determined by mass measurements in calculations rather than using an analyzed value with higher assigned uncertainty.

\section{Induction Period}

The initial stage of nitrite addition consistently shows lower ammonium destruction efficiency. However the uncertainty of the calculations is sufficiently large to make any conclusions difficult. The appearance of the results does suggest the possibility that the reaction to form nitrous acid and then to oxidize ammonium could rely on an intermediate species whose slower formation might limit the initial efficiency of the overall ammonium reaction. There are no observations that suggest that such behavior could cause a safety issue. The measurements taken do not ever conclusively prove that the efficiency is significantly lower. Much more pronounced induction periods ${ }^{3}$ are observed with formic acid denitration and those issues are studied by measuring the offgas rate during the course of the reaction. By measuring the off-gas rate (gas volume over time) along with periodic gas compositions a better understanding of the reaction could be developed. Only a limited understanding of the chemistry can be deduced from ammonium measurements alone.

\section{Solids Formation}

All of the solutions matrices tested in the current effort are simple compared to most $\mathrm{H}$ Canyon waste streams. No solids were observed to form in any experiment but the test plan (i.e. design) did not deliberately explore the potential for solids formation. When significant amounts of ammonium are present, this treatment process will introduce much more sodium than ammonium initially present in the solution and the additional sodium could result in additional solids formation. The use of $18.4 \mathrm{wt} \% \mathrm{NaNO}_{2}(3 \mathrm{M}, 1.12 \mathrm{~g} / \mathrm{cc})$ will not reduce the density if the rate of addition matches the boil-up rate as intended. The density target prior to nitrite treatment should be chosen to provide some margin to avoid excessively high density conditions that could produce large amount of solids in the evaporator.

\section{Conclusions:}

The effects of nitric acid concentration and nitrite addition rate are the major factors that affect the efficiency of ammonium destruction. Reducing the acid concentration by performing acid recovery via steam stripping prior to performing nitrite destruction of ammonium will require more nitrite due to the lower expected destruction efficiency. High rates of nitrite addition also resulted in lower efficiency. Although H-Canyon plans 
to limit the nitrite addition rate there is significant uncertainty in the scale-up of nitrite competing reactions. The nitrite addition rate makes a large difference in the destruction efficiency between the baseline rate of $0.31 \mathrm{~mL} / \mathrm{min}$ and the high rates of $1-2 \mathrm{~mL} / \mathrm{min}$. The scale-up of the baseline rate from $100 \mathrm{~mL}$ to 1600 gallon batches has significant uncertainty and poses the risk of lower efficiency at the plant scale. The practical effect of lower efficiency (if it occurs) will be the need for additional nitrite processes or dilution of the ammonium to meet limits. Experience with plant scale processing will provide increased confidence in applying the nitrite destruction of ammonium to different waste streams. Ammonium destruction processing via the semi-continuous addition of sodium nitrite should be effective for a variety of acidic H-Canyon waste streams at efficiencies that vary from less than $20 \%$ to as high as $60 \%$.

\section{Recommendations:}

Acid stripping, ammonium destruction, denitration and evaporation are all potential $\mathrm{H}$ Canyon waste processing steps. The higher efficiency of ammonium destruction by nitrite addition at $8 \mathrm{M} \mathrm{HNO}_{3}$ suggests that the sodium nitrite may be added after concentration and prior to beginning the acid stripping operation. However a decision on the order of these process operations needs to consider its effect on total waste volume and salt reduction generation. Such an evaluation was beyond the scope of this current study.

A determination on the required amount of sodium nitrite for ammonium destruction needs to consider the acid concentration of the solution in the evaporator, the nitrite addition rate, the amount of ammonium ion that requires destruction and the experience with nitrite utilization for plant scale batch sizes. Excessive addition of sodium nitrite would not be consistent with waste minimization goals.

The relatively high errors associated with ammonium solution measurement yielded high uncertainties in the destruction efficiency when the amount of ammonium remaining is greater than half the initial amount. In any future work, the nitrite addition and ammonium sampling should be continued until the ammonium is nearly completely reacted. Extending the experiments (by the use of additional nitrite) for those cases where efficiency is expected to be lower could be especially useful in producing more definitive results. Some reduction in the analytical uncertainties may be possible but the ammonium analytical uncertainty will always be significant.

No effort has been made to study the off-gas in the current study. Information on the quantity or composition of the off-gases during the course of the experiment could improve the understanding of the reaction chemistry. Some examination of the off-gas should be considered if additional work is attempted. 


\section{References:}

${ }^{1}$ E. A. Kyser, "Ammonium Destruction with Sodium Nitrite in HAW Evaporation", memo to S. A. Yano, SRNL-ATS-2007-00015, Washington Savannah River Company, Aiken, SC, March 9, 2007

${ }^{2}$ R. M. Wallace, “Ammonium Nitrate in the Vessel Vent Systems”, DPST-76-421, November 10, 1976.

${ }^{3}$ R. F. Bradley, C. B. Goodlettt, "Denitration of Nitric Acid Solutions by Formic Acid", DP-1299, June 1972

${ }^{4}$ J. E. Laurinat, "Analysis of Noncondensable Gas Generation Rate for Sodium Nitrite Addition to an Evaporator Solution Containing Ammonium Salts", X-CLC-H-00635, Washington Savannah River Company, Aiken, SC, January 22, 2007.

${ }^{5}$ J. H. Dusenbury, R. E. Powell, "Reactions of Nitrous Acid. I. Ammonium Nitrite Decomposition”, J. Am Chem Soc, 73, 3266-9 June 1951 
WSRC-STI-2007-00435, Rev 0

Appendix 


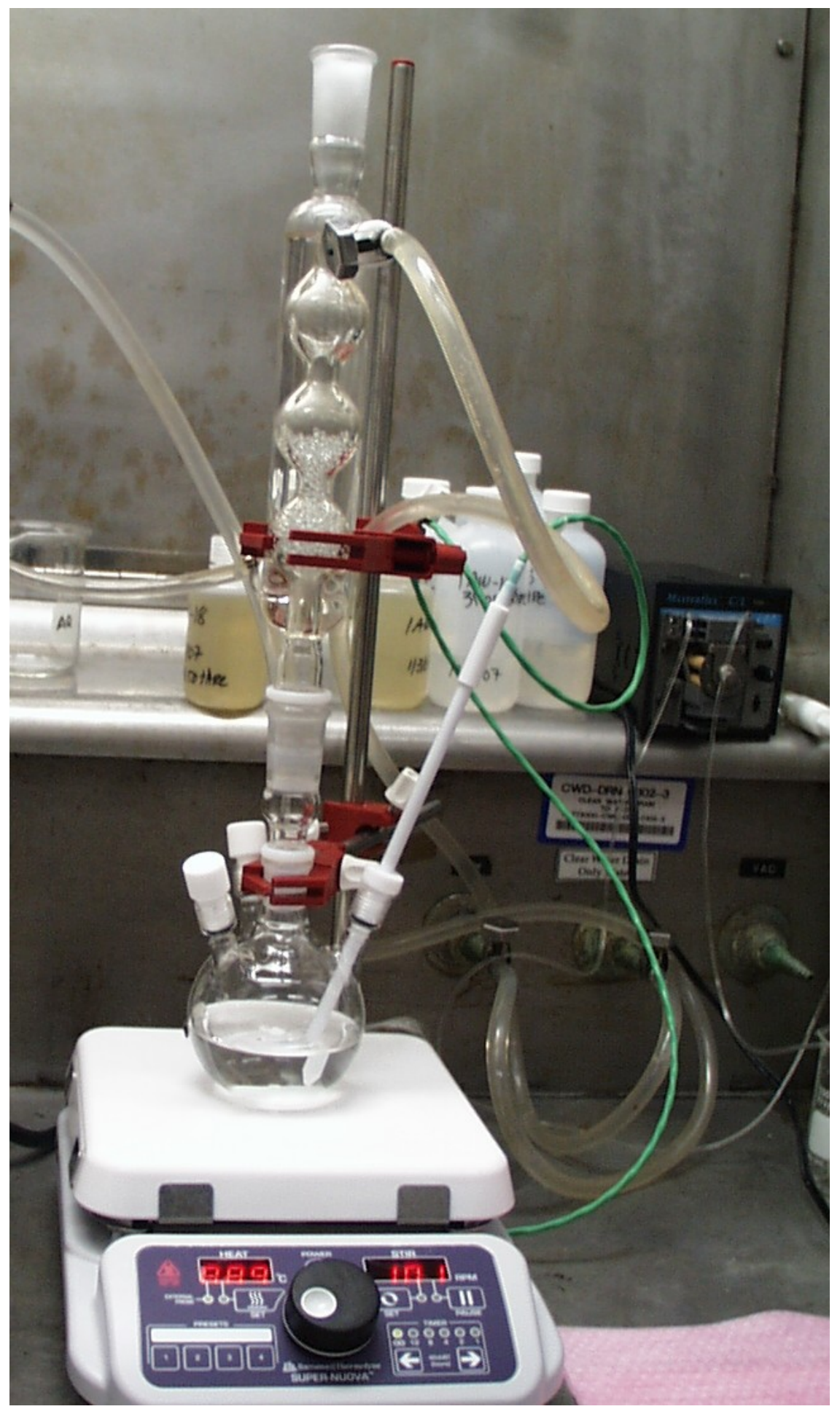

Figure 1. Laboratory Evaporator Apparatus. 


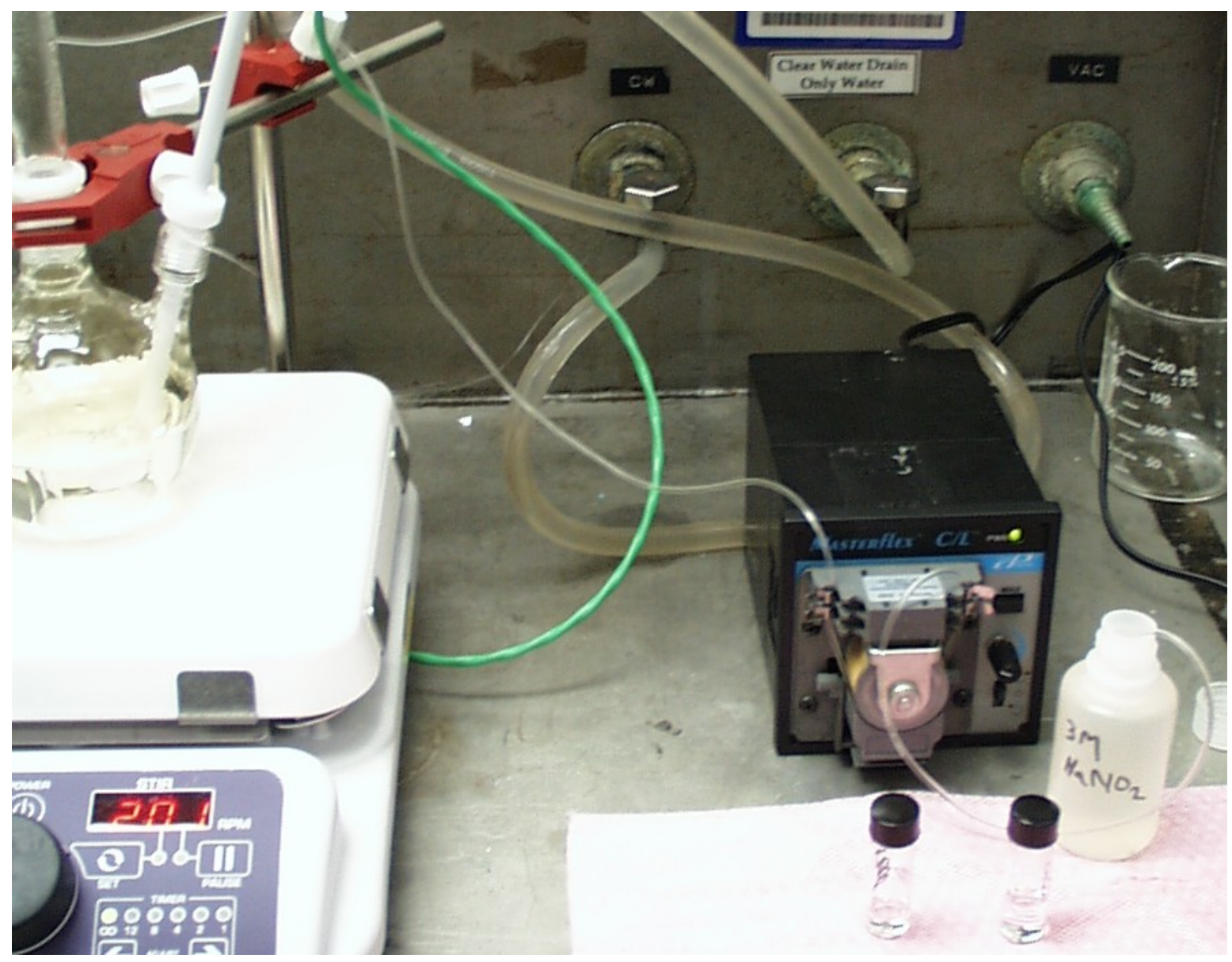

Figure 2. Feed Pump Configuration. 


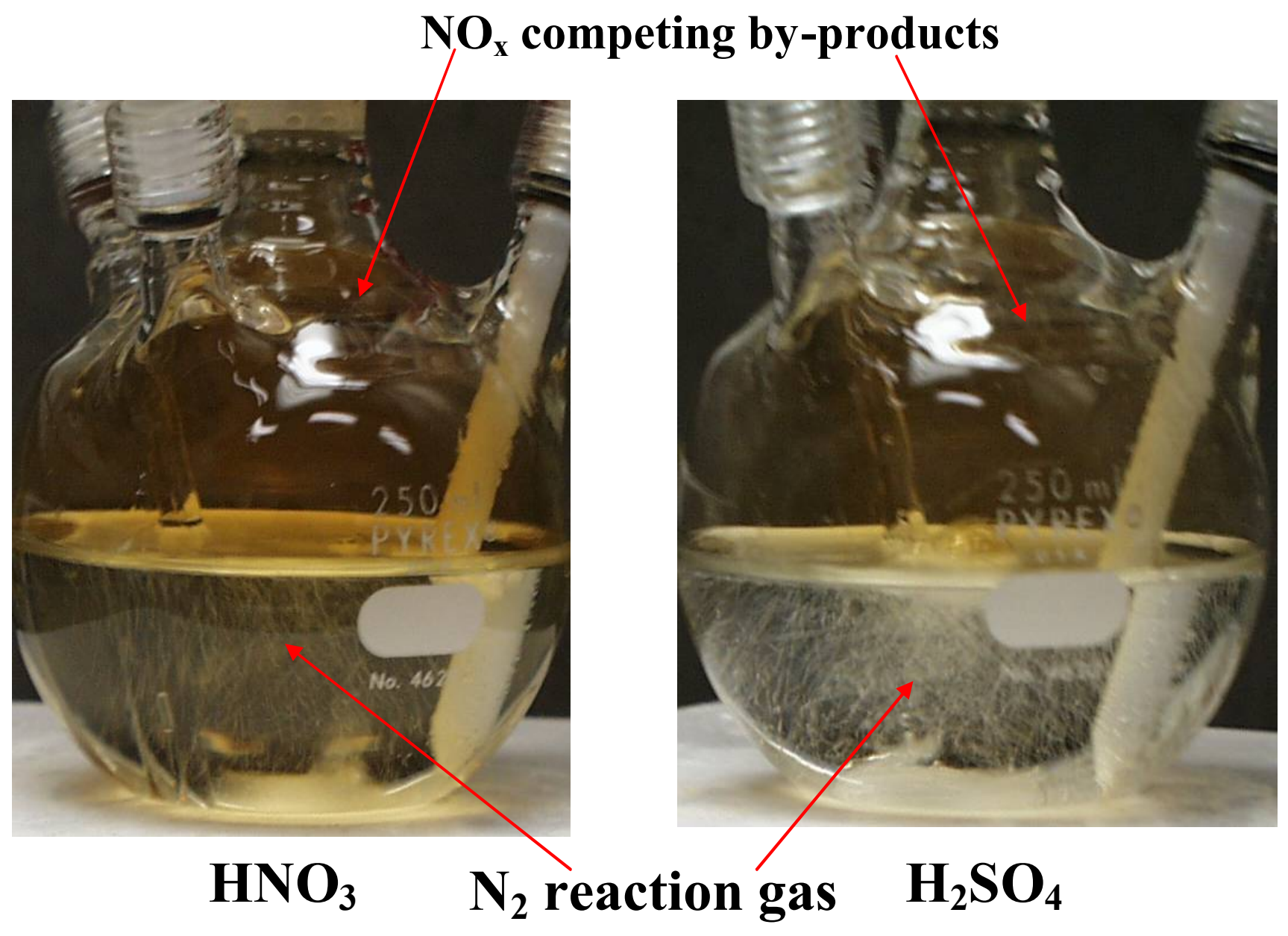

Figure 3. Reaction Vessel Showing $\mathrm{NO}_{2}$ and $\mathrm{N}_{2}$ Off-gas for $\mathrm{HNO}_{3}$ and $\mathrm{H}_{2} \mathrm{SO}_{4}$ Systems. 
Table I. Analytical Results for Flowrate Effect Tests in $5 \mathrm{M} \mathrm{HNO}_{3}$.

\begin{tabular}{|c|c|c|c|c|c|c|c|c|c|}
\hline & ID & $\begin{array}{c}\mathrm{NH}_{4}^{+} \\
\mu \mathrm{g} / \mathrm{mL}\end{array}$ & $\begin{array}{c}\mathrm{NO}_{2}^{-} \\
\mu \mathrm{g} / \mathrm{mL}\end{array}$ & $\begin{array}{c}\mathrm{NO}_{3}^{-} \\
\mu \mathrm{g} / \mathrm{mL}\end{array}$ & $\begin{array}{l}\mathrm{SO}_{4}{ }^{2-} \\
\mu \mathrm{g} / \mathrm{mL}\end{array}$ & $\begin{array}{c}\mathrm{NH}_{4}^{+} \\
\mathrm{M}\end{array}$ & $\begin{array}{c}\mathrm{NO}_{2}^{-} \\
\mathrm{M}\end{array}$ & $\begin{array}{c}\mathrm{NO}_{3}^{-} \\
\mathrm{M}\end{array}$ & $\begin{array}{c}\mathrm{SO}_{4}{ }^{2-}- \\
\mathrm{M}\end{array}$ \\
\hline HAW-22abc Feed & target & & & & & 0.254 & & 4.85 & 0.127 \\
\hline HAW-22abc Feed & $3-237272$ & 4550 & 100 & 261000 & 29600 & 0.253 & 0.002 & 4.21 & 0.308 \\
\hline HAW-22a 95C & $3-237273$ & & & & & & & & \\
\hline HAW-22a $21 \mathrm{~min}$ & $3-237274$ & 4680 & & & & 0.260 & & & \\
\hline HAW-22a 42min & $3-237275$ & 4290 & & & & 0.238 & & & \\
\hline HAW-22 3M NO2 & target & & & & & & 3.03 & & \\
\hline HAW-22 3M NO2 & $3-237278$ & 100 & 130000 & 300 & 50 & 0.006 & 2.83 & 0.00 & 0.001 \\
\hline HAW-22abc Feed & target & & & & & 0.254 & & 4.85 & 0.127 \\
\hline HAW-22aa 95C & $3-237366$ & 4810 & & & & 0.267 & & & \\
\hline HAW-22aa $21 \mathrm{~min}$ & $3-237367$ & 3650 & & & & 0.203 & & & \\
\hline HAW-22aa 42min & $3-237368$ & 2010 & & & & 0.112 & & & \\
\hline HAW-22abc Feed & target & & & & & 0.254 & & 4.85 & 0.127 \\
\hline HAW-22b 95C & $3-237379$ & 4720 & & & & 0.262 & & & \\
\hline HAW-22b $150 \mathrm{~min}$ & $3-237380$ & 2880 & & & & 0.160 & & & \\
\hline HAW-22b 300min & $3-237381$ & 102 & & & & 0.006 & & & \\
\hline HAW-22b 310min & $3-237382$ & & & & & & & & \\
\hline HAW-22b final & $3-237383$ & & & & & & & & \\
\hline HAW-22abc Feed & target & & & & & 0.254 & & 4.85 & 0.127 \\
\hline HAW-22c 95C & $3-237385$ & 4480 & & & & 0.249 & & & \\
\hline HAW-22c $4 \mathrm{~min}$ & $3-237386$ & 4180 & & & & 0.232 & & & \\
\hline HAW-22c $8 \mathrm{~min}$ & $3-237387$ & 3810 & & & & 0.212 & & & \\
\hline HAW-22c $18 \mathrm{~min}$ & $3-237388$ & 3310 & & & & 0.184 & & & \\
\hline HAW-22c final & $3-237389$ & 3320 & & & & 0.184 & & & \\
\hline HAW-22abc Feed & target & & & & & 0.254 & & 4.85 & 0.127 \\
\hline HAW-22abc Feed & $3-237272$ & 4550 & 100 & 261000 & 29600 & & & & \\
\hline HAW-22ca 95C & $3-240456$ & 4440 & & & & & & & \\
\hline HAW-22ca 4min & $3-240457$ & 4020 & & & & & & & \\
\hline HAW-22ca $8 \mathrm{~min}$ & $3-240458$ & 2210 & & & & & & & \\
\hline HAW-22ca $18 \mathrm{~min}$ & $3-240459$ & 1910 & & & & & & & \\
\hline HAW-22ca final & $3-240460$ & 1340 & & & & & & & \\
\hline $3 \mathrm{M} \mathrm{HNO} 2$ & $3-240597$ & & 121000 & 100 & 100 & & 2.63 & 0.002 & 0.001 \\
\hline
\end{tabular}

* Note: HAW-xx is the designation for sample ID's as submitted to AD LIMS for analysis that identifies the individual samples. 
Table II. Analytical Results for Flowrate Effect Tests in 4.6 $\mathrm{M} \mathrm{H}_{2} \mathrm{SO}_{4}$.

\begin{tabular}{lccccccccc}
\hline & ID & $\mathrm{NH}_{4}^{+}$ & $\mathrm{NO}_{2}{ }^{-}$ & $\mathrm{NO}_{3}{ }^{-}$ & $\mathrm{SO}_{4}{ }^{-2}-$ & $\mathrm{NH}_{4}{ }^{+}$ & $\mathrm{NO}_{2}{ }^{-}$ & $\mathrm{NO}_{3}^{-}$ & $\mathrm{SO}_{4}{ }^{-2}-$ \\
& & $\mu \mathrm{g} / \mathrm{mL}$ & $\mu \mathrm{g} / \mathrm{mL}$ & $\mu \mathrm{g} / \mathrm{mL}$ & $\mu \mathrm{g} / \mathrm{mL}$ & $\mathrm{M}$ & $\mathrm{M}$ & $\mathrm{M}$ & $\mathrm{M}$ \\
\hline HAW-22edf Feed & target & & & & & 0.249 & & 0.000 & 4.59 \\
HAW-22edf Feed & $3-237279$ & 4460 & 100 & 89 & 336000 & 0.248 & 0.002 & 0.001 & 3.50 \\
HAW-22d 95C & $3-237280$ & 4470 & 100 & 152 & 350000 & 0.248 & 0.002 & 0.002 & 3.65 \\
HAW-22d 21min & $3-237281$ & 4090 & 100 & 2720 & 323000 & 0.227 & 0.002 & 0.044 & 3.36 \\
HAW-22d 42min & $3-237282$ & 2800 & 100 & 5260 & 304000 & 0.156 & 0.002 & 0.085 & 3.17 \\
HAW-22d 52min & $3-237283$ & 2210 & 100 & 5380 & 304000 & 0.123 & 0.002 & 0.087 & 3.17 \\
HAW-22d final & $3-237284$ & 2150 & 100 & 6130 & 311000 & 0.119 & 0.002 & 0.099 & 3.24 \\
HAW-22e 95C & $3-237374$ & 4580 & 100 & 3280 & 387000 & 0.254 & 0.002 & 0.05 & 4.03 \\
HAW-22e 150min & $3-237375$ & 3170 & 100 & 5300 & 361000 & 0.176 & 0.002 & 0.09 & 3.76 \\
HAW-22e 300min & $3-237376$ & 853 & 100 & 9560 & 334000 & 0.047 & 0.002 & 0.15 & 3.48 \\
HAW-22edf Feed & target & & & & & 0.249 & & 0.000 & 4.59 \\
HAW-22f 95C & $3-237390$ & 4360 & 100 & 304 & 388000 & 0.242 & 0.002 & 0.005 & 4.04 \\
HAW-22f 4min & $3-237391$ & 4250 & 100 & 3220 & 366000 & 0.236 & 0.002 & 0.052 & 3.81 \\
HAW-22f 8min & $3-237392$ & 4000 & 100 & 5590 & 351000 & 0.222 & 0.002 & 0.090 & 3.66 \\
HAW-22f 18min & $3-237393$ & 3880 & 100 & 5590 & 336000 & 0.216 & 0.002 & 0.090 & 3.50 \\
HAW-22f final & $3-237394$ & 3690 & 100 & 6020 & 342000 & 0.205 & 0.002 & 0.097 & 3.56 \\
HAW-22edf Feed & target & & & & & 0.249 & & 0.000 & 4.59 \\
HAW-22edf Feed & $3-237279$ & 4460 & 100 & 89 & 336000 & 0.248 & 0.002 & 0.001 & 3.50 \\
HAW-22fa 95C & $3-240451$ & 4220 & 100 & 100 & 376000 & 0.234 & 0.002 & 0.002 & 3.92 \\
HAW-22fa 4min & $3-240452$ & 4100 & 100 & 3860 & 353000 & 0.228 & 0.002 & 0.062 & 3.68 \\
HAW-22fa 8min & $3-240453$ & 3160 & 100 & 6290 & 342000 & 0.176 & 0.002 & 0.101 & 3.56 \\
HAW-22fa 18min & $3-240454$ & 2860 & 100 & 5620 & 343000 & 0.159 & 0.002 & 0.091 & 3.57 \\
HAW-22fa final & $3-240455$ & 2820 & 100 & 6850 & 342000 & 0.157 & 0.002 & 0.110 & 3.56 \\
\hline
\end{tabular}

* Note: HAW-xx is the designation for sample ID's as submitted to AD LIMS for analysis that identifies the individual samples. 
Table III. Analytical Results for $\mathrm{HNO}_{3}$ Concentration Effect Tests.

\begin{tabular}{|c|c|c|c|c|c|c|c|c|c|}
\hline & ID & $\begin{array}{c}\mathrm{NH}_{4}^{+} \\
\mu \mathrm{g} / \mathrm{mL}\end{array}$ & $\begin{array}{c}\mathrm{NO}_{2}^{-} \\
\mu \mathrm{g} / \mathrm{mL}\end{array}$ & $\begin{array}{c}\mathrm{NO}_{3}^{-} \\
\mu \mathrm{g} / \mathrm{mL}\end{array}$ & $\begin{array}{l}\mathrm{SO}_{4}{ }^{2-}- \\
\mu \mathrm{g} / \mathrm{mL}\end{array}$ & $\begin{array}{c}\mathrm{NH}_{4}^{+} \\
\mathrm{M}\end{array}$ & $\begin{array}{c}\mathrm{NO}_{2}^{-} \\
\mathrm{M}\end{array}$ & $\begin{array}{c}\mathrm{NO}_{3}^{-} \\
\mathrm{M}\end{array}$ & $\begin{array}{c}\mathrm{SO}_{4}{ }^{2-} . \\
\mathrm{M}\end{array}$ \\
\hline HAW-23abc & target & & & & & 0.250 & & & 0.125 \\
\hline HAW-23a Feed & $3-237501$ & & & & & & & & \\
\hline HAW-23a 95C & $3-237502$ & 4570 & & & & 0.254 & & & \\
\hline HAW-23a $21 \mathrm{~min}$ & $3-237503$ & 3920 & & & & 0.218 & & & \\
\hline HAW-23a 42min & $3-237504$ & 2000 & & & & 0.111 & & & \\
\hline HAW-23a 52min & $3-237505$ & 1940 & & & & 0.108 & & & \\
\hline HAW-23a final & $3-237506$ & 1650 & & & & 0.092 & & & \\
\hline HAW-23aa & target & & & & & 0.251 & & 1.98 & 0.124 \\
\hline HAW-23aa Feed & $3-240461$ & 4390 & 100 & 117000 & 11900 & 0.244 & 0.002 & 1.89 & 0.124 \\
\hline HAW-23aa 95C & $3-240462$ & 4340 & 100 & 114000 & 11400 & 0.241 & 0.002 & 1.84 & 0.119 \\
\hline HAW-23aa $21 \mathrm{~min}$ & $3-240463$ & 3440 & 61 & 111000 & 10800 & 0.191 & 0.001 & 1.79 & 0.113 \\
\hline HAW-23aa $42 \mathrm{~min}$ & $3-240464$ & 1940 & 61 & 110000 & 10400 & 0.108 & 0.001 & 1.77 & 0.108 \\
\hline HAW-23aa $52 \mathrm{~min}$ & $3-240465$ & 1930 & 42 & 109000 & 10400 & 0.107 & 0.001 & 1.76 & 0.108 \\
\hline HAW-23aa final & $3-240466$ & 1560 & 66 & 109000 & 10400 & 0.087 & 0.001 & 1.76 & 0.108 \\
\hline HAW-23b Feed & $3-237507$ & & & & & & & & \\
\hline HAW-23b 95C & $3-237508$ & 4630 & & & & 0.257 & & & \\
\hline HAW-23b $21 \mathrm{~min}$ & $3-237509$ & 2930 & & & & 0.163 & & & \\
\hline HAW-23b 42min & $3-237510$ & 820 & & & & 0.046 & & & \\
\hline HAW-23b $52 \mathrm{~min}$ & $3-237511$ & & & & & & & & \\
\hline HAW-23b final & $3-237512$ & & & & & & & & \\
\hline HAW-23c Feed & $3-237495$ & & & & & & & & \\
\hline HAW-23c 95C & $3-237496$ & 4590 & & & & 0.255 & & & \\
\hline HAW-23c $21 \mathrm{~min}$ & $3-237497$ & 2600 & & & & 0.144 & & & \\
\hline HAW-23c $42 \mathrm{~min}$ & $3-237498$ & 100 & & & & 0.006 & & & \\
\hline HAW-23c 52min & $3-237499$ & & & & & & & & \\
\hline HAW-23c final & $3-237500$ & & & & & & & & \\
\hline
\end{tabular}

* Note: HAW-xx is the designation for sample ID's as submitted to AD LIMS for analysis that identifies the individual samples. 


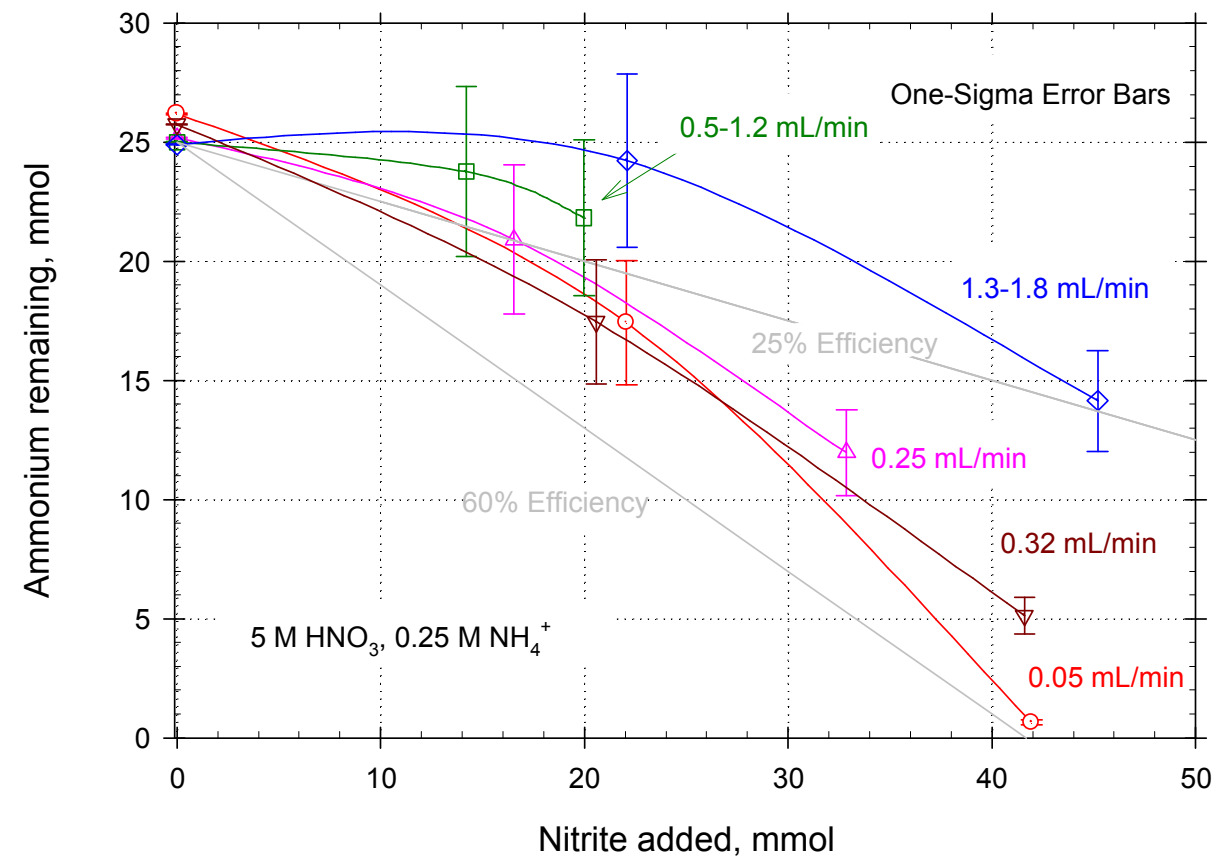

Figure 4. Effect of Nitrite Addition Rate on Ammonium Destruction vs. Quantity of Nitrite Added (molar basis) in $5 \mathrm{M} \mathrm{HNO}_{3}$.

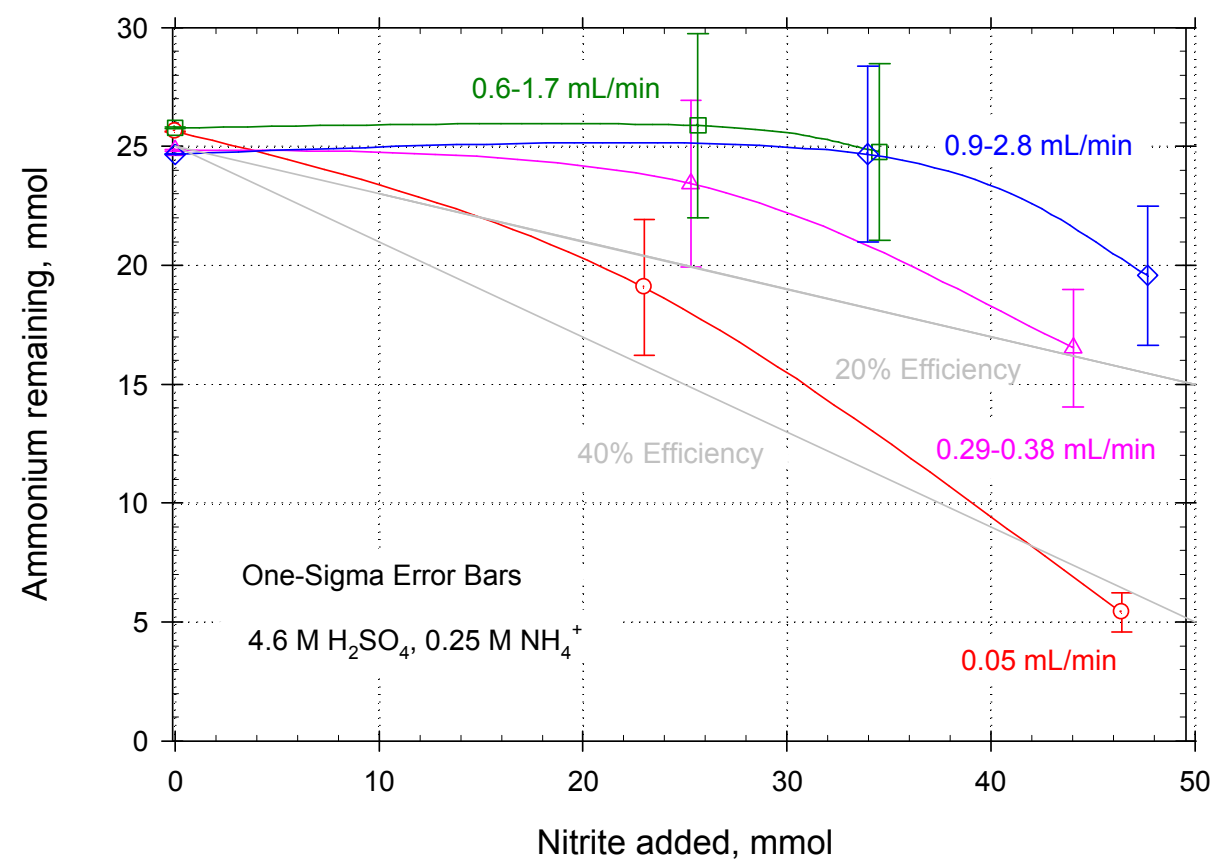

Figure 5. Effect of Nitrite Addition Rate on Ammonium Destruction vs. Quantity of Nitrite Added (molar basis) in 4.6 $\mathrm{M} \mathrm{H}_{2} \mathrm{SO}_{4}$. 


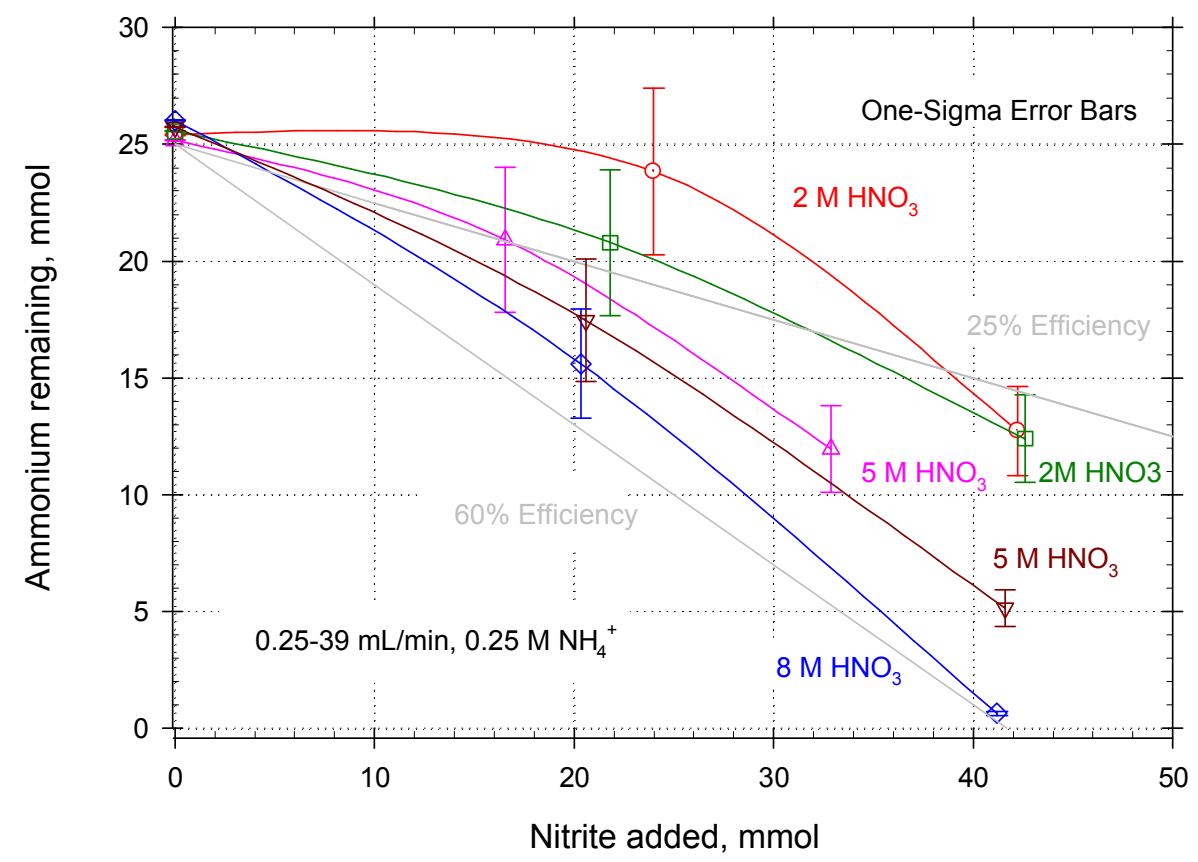

Figure 6. Effect of $\mathrm{HNO}_{3}$ Concentration on Ammonium Destruction vs. Quantity of Nitrite Added (molar basis). 


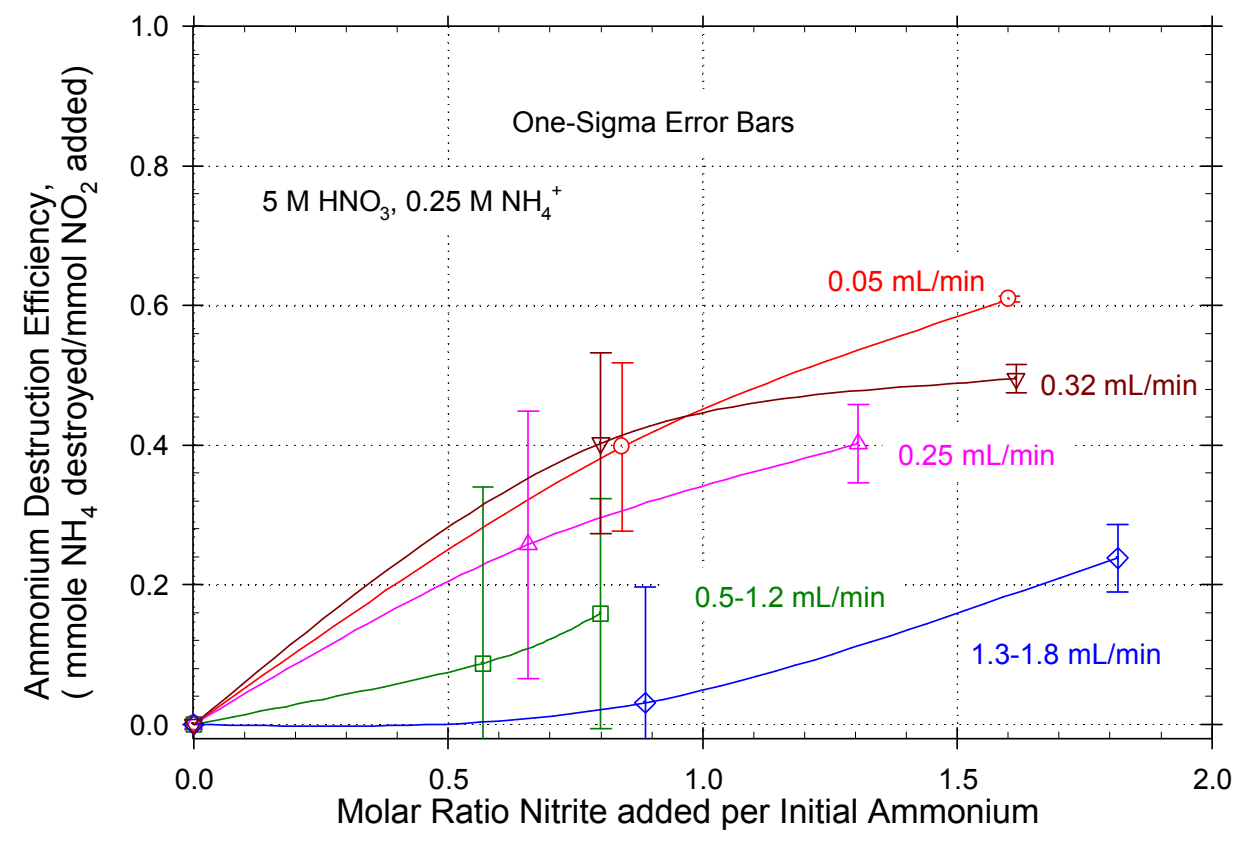

Figure 7. Effect of Nitrite Addition Rate on Cumulative Ammonium Destruction Efficiency in $5 \mathrm{M} \mathrm{HNO}_{3}$.

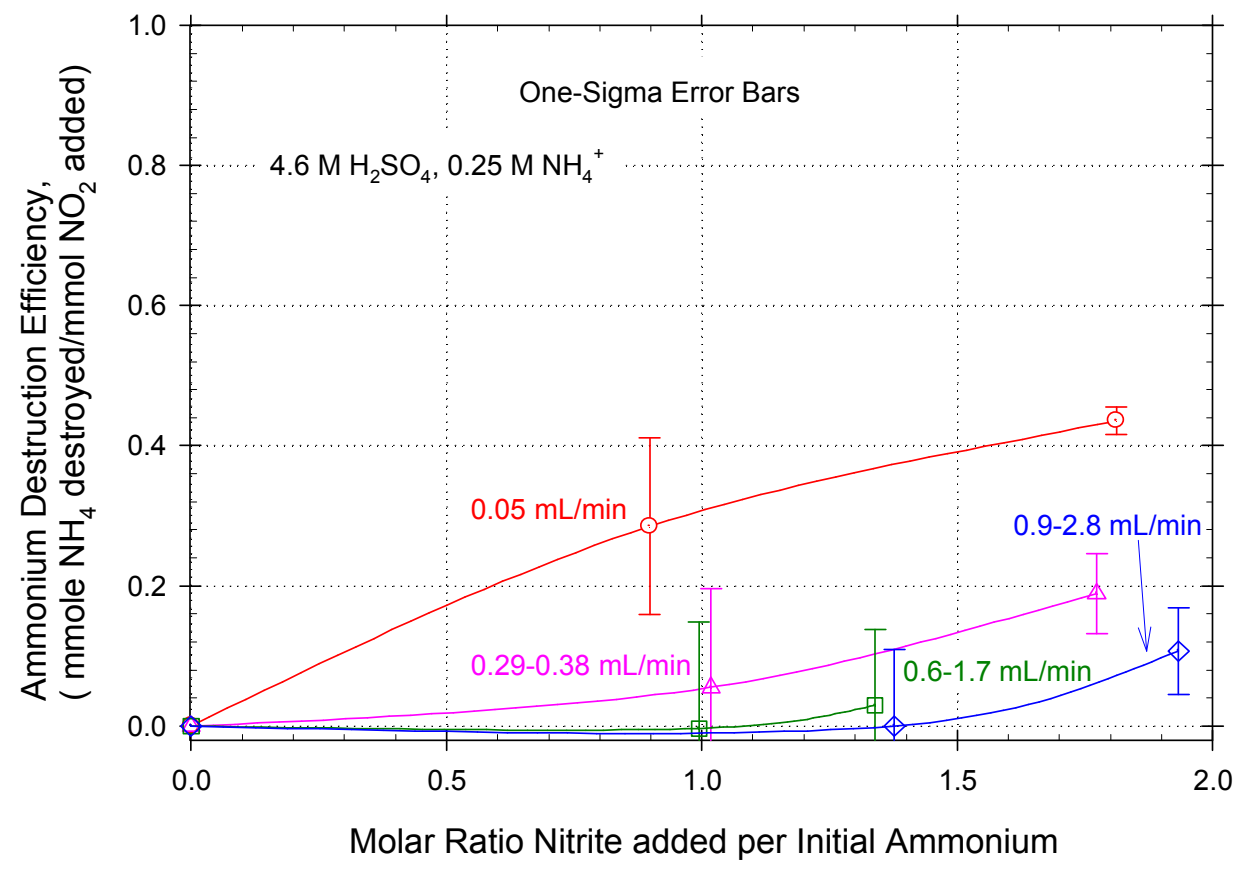

Figure 8. Effect of Nitrite Addition Rate on Cumulative Ammonium Destruction Efficiency in 4.6 $\mathrm{M} \mathrm{H}_{2} \mathrm{SO}_{4}$. 


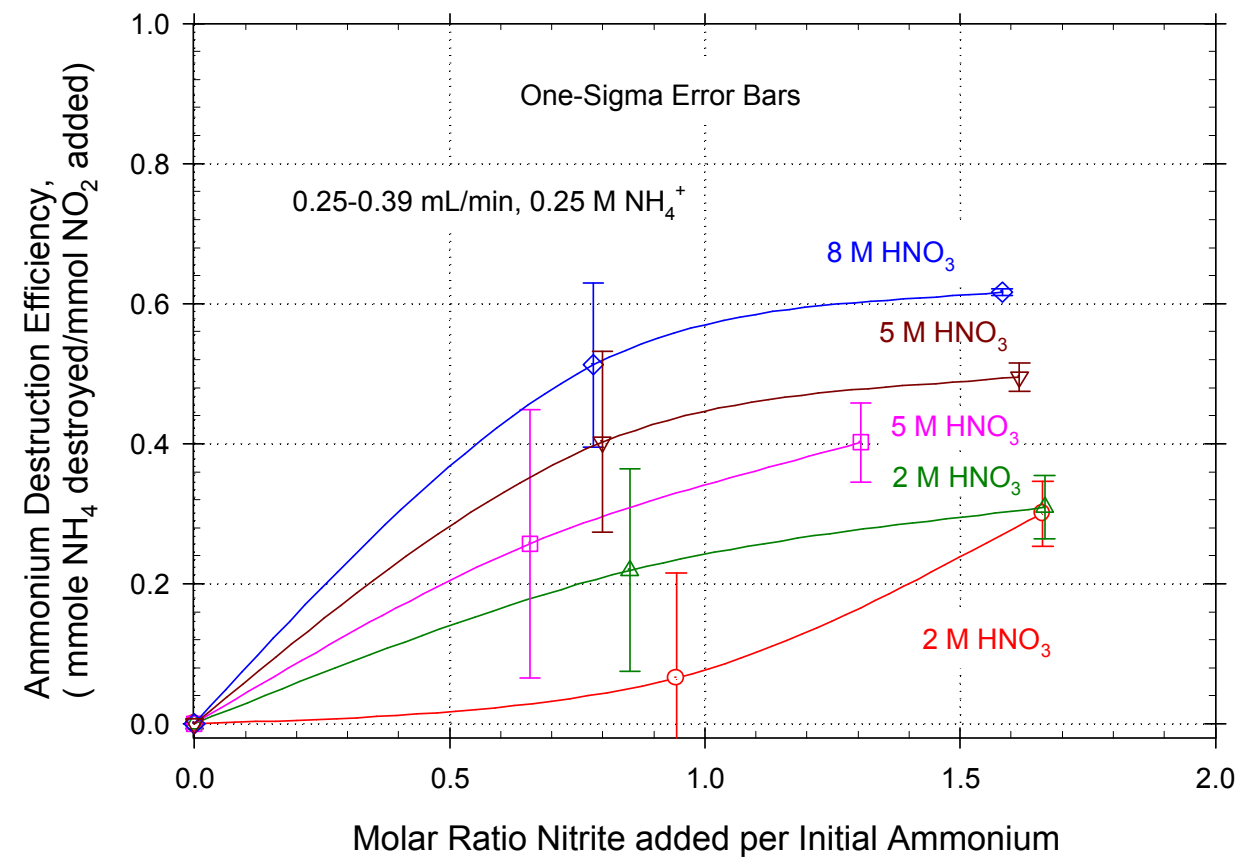

Figure 9. Effect of $\mathrm{HNO}_{3}$ Concentration Addition Rate on Cumulative Ammonium Destruction Efficiency. 
Table IV. Data and Calculations from Flowrate Effect Tests in $5 \mathrm{M} \mathrm{HNO}_{3}$.

\begin{tabular}{|c|c|c|c|c|c|c|c|c|c|c|c|c|c|}
\hline & & $\begin{array}{c}\text { Pot } \\
\mathrm{g}\end{array}$ & $\begin{array}{l}\text { Pot } \\
\mathrm{mL}\end{array}$ & $\begin{array}{c}\text { Sample } \\
\mathrm{g}\end{array}$ & $\begin{array}{c}\text { Nitrite } \\
\mathrm{g}\end{array}$ & $\begin{array}{c}\text { Nitrite } \\
\mathrm{mL}\end{array}$ & $\begin{array}{l}\text { Nitrite } \\
\mathrm{mL} / \mathrm{min}\end{array}$ & $\begin{array}{l}\text { Nitrite } \\
\text { mmol }\end{array}$ & $\begin{array}{c}\mathrm{NH}_{4}^{+} \\
\mathrm{M}\end{array}$ & $\begin{array}{l}\mathrm{NH}_{4}^{+} \\
\mathrm{mmol}\end{array}$ & $\mathrm{NO}_{2}{ }^{-} / \mathrm{NH}_{4}{ }^{+}$ & $\begin{array}{l}\Delta \mathrm{NH}_{4}^{+} / \mathrm{NO}_{2}{ }^{-} \\
\text {incremental }\end{array}$ & cumulative \\
\hline $3 / 27 / 2007$ & HAW-22aa & & & & & & & & & & & & \\
\hline $13: 53$ & Start Hotplate & 114.6 & 99 & & & & & & 0.254 & 25.2 & & & \\
\hline $14: 20$ & 95C sample/Start Nitrite & 114.6 & 99 & 1.35 & 87.63 & & & & 0.267 & 26.5 & & & \\
\hline $14: 42$ & sample & 119.4 & 103 & 1.35 & 81.51 & 5.4 & 0.25 & 16.6 & 0.203 & 20.9 & 0.626 & 0.33 & 0.33 \\
\hline $15: 03$ & Stop nitrite/sample & 124.1 & 107 & 1.25 & 75.48 & 10.8 & 0.26 & 32.9 & 0.112 & 12.0 & 1.242 & 0.55 & 0.44 \\
\hline $15: 13$ & heat off/ sample & 122.8 & 106 & 1.32 & 75.48 & 10.8 & & & & 12.0 & 1.242 & & \\
\hline $7: 30$ & Cooled/Sample & 121.5 & 105 & 1.68 & 75.48 & 10.8 & & & & 12.0 & 1.242 & & \\
\hline $3 / 28 / 2007$ & HAW-22b & & & & & & & & & & & & \\
\hline $8: 46$ & Start Hotplate & 119.3 & 103 & & & & & & 0.254 & 26.2 & & & \\
\hline $8: 15$ & 95C sample/Start Nitrite & 119.3 & 103 & 1.33 & 108.58 & & & & 0.262 & 27.0 & & & \\
\hline $10: 45$ & sample & 126.1 & 109 & 1.20 & 100.41 & 7.3 & 0.05 & 22.1 & 0.160 & 17.4 & 0.817 & 0.43 & 0.43 \\
\hline $13: 10$ & Stop nitrite/sample & 132.3 & 114 & 1.69 & 93.04 & 13.8 & 0.05 & 42.0 & 0.006 & 0.6 & 1.553 & 0.84 & 0.63 \\
\hline $13: 25$ & heat off/ sample & 130.6 & 113 & 1.33 & 93.04 & 13.8 & & & & 0.6 & 1.553 & & \\
\hline $14: 25$ & Cooled/Sample & 156.6 & 137 & 1.24 & 93.04 & 13.8 & & & & 0.6 & 1.553 & & \\
\hline $3 / 30 / 2007$ & HAW-22c & & & & & & & & & & & & \\
\hline $9: 10$ & Start Hotplate & 114.5 & 99 & & & & & & 0.253 & 25.0 & & & \\
\hline $9: 37$ & 95C sample/Start Nitrite & 114.5 & 99 & 1.29 & 89.80 & & & & 0.249 & 24.6 & & & \\
\hline $9: 41$ & sample & 118.5 & 102 & 1.19 & 84.55 & 4.7 & 1.17 & 14.2 & 0.232 & 23.8 & 0.577 & 0.06 & 0.06 \\
\hline $9: 45$ & Stop nitrite/sample & 119.4 & 103 & 1.24 & 82.41 & 6.6 & 0.48 & 20.0 & 0.212 & 21.8 & 0.812 & 0.33 & 0.14 \\
\hline 9:56 & heat off/ sample & 118.2 & 102 & 1.74 & 82.41 & 6.6 & & & 0.184 & 21.8 & 0.812 & & \\
\hline 10:08 & Cooled/Sample & 112.2 & 99 & 1.50 & & & & & 0.184 & 21.8 & 9.869 & & \\
\hline $6 / 26 / 2007$ & HAW-22ca & & & & & & & & & & & & \\
\hline $7: 30$ & Start Hotplate & 118.3 & 103 & & 89.26 & & & & 0.243 & 24.9 & & & \\
\hline 8:01 & 95C sample/Start Nitrite & 118.3 & 102 & 0.87 & 89.26 & & & & 0.247 & 25.2 & & & \\
\hline 8:05 & sample & 125.6 & 108 & 0.74 & 81.06 & 7.3 & 1.82 & 22.1 & 0.223 & 24.2 & 0.877 & 0.04 & 0.04 \\
\hline $8: 11$ & Stop nitrite/sample & 133.4 & 115 & 0.98 & 72.49 & 14.9 & 1.27 & 45.2 & 0.123 & 14.1 & 1.794 & 0.44 & 0.24 \\
\hline $8: 21$ & heat off/sample & 132.4 & 114 & 0.78 & 72.49 & 14.9 & & & 0.106 & 14.1 & 1.794 & & \\
\hline $13: 15$ & Cooled/Sample & 127.0 & 111 & 0.94 & 72.49 & 14.9 & & & 0.074 & 14.1 & 1.794 & & \\
\hline
\end{tabular}


Table V. Data and Calculations from Flowrate Effect Tests in 4.6 $\mathrm{M} \mathrm{H}_{2} \mathrm{SO}_{4}$.

\begin{tabular}{|c|c|c|c|c|c|c|c|c|c|c|c|c|c|}
\hline & & $\begin{array}{c}\text { Pot } \\
\mathrm{g}\end{array}$ & $\begin{array}{l}\text { Pot } \\
\mathrm{mL}\end{array}$ & $\begin{array}{c}\text { Sample } \\
\mathrm{g}\end{array}$ & $\begin{array}{c}\text { Nitrite } \\
\mathrm{g}\end{array}$ & $\begin{array}{c}\text { Nitrite } \\
\mathrm{mL}\end{array}$ & $\begin{array}{l}\text { Nitrite } \\
\mathrm{mL} / \mathrm{min}\end{array}$ & $\begin{array}{l}\text { Nitrite } \\
\text { mmol }\end{array}$ & $\begin{array}{c}\mathrm{NH}_{4}^{+} \\
\mathrm{M}\end{array}$ & $\begin{array}{l}\mathrm{NH}_{4}^{+} \\
\text {mmol }\end{array}$ & $\mathrm{NO}_{2} / \mathrm{NH}_{4}^{+}$ & $\begin{array}{l}\Delta \mathrm{NH}_{4}^{+} / \mathrm{NO}_{2}^{-} \\
\text {incremental }\end{array}$ & cumulative \\
\hline $3 / 27 / 2007$ & HAW-22d & & & & & & & & & & & & \\
\hline $9: 17$ & Start Hotplate & 126.5 & 100 & & & & & & 0.249 & 24.8 & & & \\
\hline $9: 47$ & 95C sample/Start Nitrite & 124.4 & 98 & 1.30 & 104.42 & & & & 0.248 & 24.3 & & & \\
\hline 10:09 & sample & 131.0 & 103 & 1.62 & 95.07 & 8.3 & 0.38 & 25.3 & 0.227 & 23.4 & 1.039 & 0.04 & 0.04 \\
\hline $10: 30$ & Stop nitrite/sample & 134.9 & 106 & 1.50 & 88.14 & 14.5 & 0.29 & 44.0 & 0.156 & 16.5 & 1.809 & 0.37 & 0.18 \\
\hline $10: 41$ & heat off/ sample & 132.6 & 104 & 1.73 & 88.14 & 14.5 & & & 0.123 & 12.8 & 1.809 & & \\
\hline 13:07 & Cooled/Sample & 128.8 & 101 & 1.39 & 88.14 & 14.5 & & & 0.119 & 12.1 & 1.809 & & \\
\hline $3 / 29 / 2007$ & HAW-22e & & & & & & & & & & & & \\
\hline $7: 48$ & Start Hotplate & 130.7 & 103 & & & & & & 0.249 & 25.6 & & & \\
\hline $8: 15$ & 95C sample/Start Nitrite & 130.7 & 103 & 1.53 & 106.99 & & & & 0.254 & 26.1 & & & \\
\hline $10: 45$ & sample & 137.7 & 108 & 1.26 & 98.47 & 7.6 & 0.05 & 23.0 & 0.176 & 19.1 & 0.880 & 0.31 & 0.31 \\
\hline $13: 20$ & Stop nitrite/sample & 145.1 & 114 & 1.68 & 89.80 & 15.3 & 0.05 & 46.4 & 0.047 & 5.4 & 1.775 & 0.58 & 0.45 \\
\hline $13: 33$ & heat off/ sample & 143.4 & 113 & 1.59 & 89.80 & 15.3 & & & & 5.4 & 1.775 & & \\
\hline $14: 29$ & Cooled/Sample & 134.5 & 109 & 1.82 & & 95.1 & 1.43 & 242.4 & & 5.4 & 11.047 & & \\
\hline $3 / 30 / 2007$ & HAW-22f & & & & & & & & & & & & \\
\hline $12: 50$ & Start Hotplate & 130.7 & 103 & & & & & & 0.249 & 25.8 & & & \\
\hline $13: 14$ & 95C sample/Start Nitrite & 130.7 & 103 & 1.68 & 82.46 & & & & 0.242 & 25.0 & & & \\
\hline $13: 19$ & sample & 138.5 & 110 & 0.94 & 72.98 & 8.4 & 1.69 & 25.6 & 0.236 & 25.9 & 1.024 & -0.03 & -0.03 \\
\hline $13: 24$ & Stop nitrite/sample & 140.9 & 111 & 1.53 & 69.69 & 11.4 & 0.59 & 34.5 & 0.222 & 24.8 & 1.379 & 0.12 & 0.01 \\
\hline $13: 35$ & heat off/ sample & 139.3 & 110 & 1.44 & 69.69 & 11.4 & & & 0.216 & 24.8 & 1.379 & & \\
\hline $13: 47$ & Cooled/Sample & 124.5 & 102 & 1.44 & & 73.4 & 5.17 & 188.5 & 0.205 & 24.8 & 8.903 & & \\
\hline $6 / 25 / 2007$ & HAW-22fa & & & & & & & & & & & & \\
\hline $12: 47$ & Start Hotplate & 125.3 & 99 & & 106.89 & & & & 0.249 & 24.7 & & & \\
\hline $13: 15$ & 95C sample/Start Nitrite & 125.3 & 99 & 1.01 & 106.89 & & & & 0.234 & 23.2 & & & \\
\hline $13: 19$ & sample & 136.9 & 108 & 1.06 & 94.33 & 11.2 & 2.80 & 34.0 & 0.228 & 24.7 & 1.461 & -0.04 & -0.04 \\
\hline $13: 24$ & Stop nitrite/sample & 140.9 & 111 & 1.03 & 89.26 & 15.7 & 0.90 & 47.7 & 0.176 & 19.6 & 2.051 & 0.37 & 0.08 \\
\hline $13: 34$ & heat off/ sample & 139.9 & 111 & 1.24 & 89.26 & 15.7 & & & 0.159 & 19.6 & 2.051 & & \\
\hline $14: 50$ & Cooled/Sample & 132.2 & 106 & 1.14 & 89.26 & 15.7 & & & 0.157 & 19.6 & 2.051 & & \\
\hline
\end{tabular}


Table VI. Data and Calculations from for $\mathrm{HNO}_{3}$ Concentration Effect Tests.

\begin{tabular}{|c|c|c|c|c|c|c|c|c|c|c|c|c|c|}
\hline & & $\begin{array}{c}\text { Pot } \\
\mathrm{g}\end{array}$ & $\begin{array}{l}\text { Pot } \\
\mathrm{mL}\end{array}$ & $\begin{array}{c}\text { Sample } \\
\mathrm{g}\end{array}$ & $\begin{array}{c}\text { Nitrite } \\
\mathrm{g}\end{array}$ & $\begin{array}{c}\text { Nitrite } \\
\mathrm{mL}\end{array}$ & $\begin{array}{l}\text { Nitrite } \\
\mathrm{mL} / \mathrm{min}\end{array}$ & $\begin{array}{l}\text { Nitrite } \\
\text { mmol }\end{array}$ & $\begin{array}{c}\mathrm{NH}_{4}^{+} \\
\mathrm{M}\end{array}$ & $\begin{array}{l}\mathrm{NH}_{4}^{+} \\
\mathrm{mmol}\end{array}$ & $\mathrm{NO}_{2}{ }^{-} / \mathrm{NH}_{4}{ }^{+}$ & $\begin{array}{l}\Delta \mathrm{NH}_{4}^{+} / \mathrm{NO}_{2}^{-} \\
\text {incremental }\end{array}$ & cumulative \\
\hline $6 / 26 / 2007$ & HAW-23aa & & & & & & & & & & & & \\
\hline $13: 55$ & Start Hotplate & 108.6 & 102 & & & & & & 0.251 & 25.6 & & & \\
\hline $14: 15$ & 95C sample/Start Nitrite & 108.6 & 102 & 0.74 & 69.43 & & & & 0.241 & 24.6 & & & \\
\hline $14: 36$ & sample & 116.0 & 109 & 1.04 & 61.36 & 7.2 & 0.34 & 21.8 & 0.191 & 20.8 & 0.888 & 0.17 & 0.17 \\
\hline $14: 57$ & Stop nitrite/sample & 122.6 & 115 & 1.15 & 53.66 & 14.0 & 0.33 & 42.6 & 0.108 & 12.4 & 1.733 & 0.40 & 0.29 \\
\hline 15:07 & heat off/ sample & 121.5 & 114 & 1.09 & 53.66 & 14.0 & & & 0.107 & 12.2 & 1.733 & & \\
\hline $6: 50$ & Cooled/Sample & 120.4 & 113 & 1.04 & 53.66 & 14.0 & & & 0.087 & 9.8 & 1.733 & & \\
\hline $4 / 2 / 2007$ & HAW-23a & & & & & & & & & & & & \\
\hline $12: 35$ & Start Hotplate & 109.0 & 102 & & & & & & 0.248 & 25.4 & & & \\
\hline $12: 58$ & 95C sample/Start Nitrite & 109.0 & 102 & 1.15 & 93.44 & & & & 0.254 & 26.0 & & & \\
\hline $13: 18$ & sample & 116.7 & 109 & 1.27 & 84.87 & 7.9 & 0.39 & 24.0 & 0.218 & 23.8 & 0.924 & 0.09 & 0.09 \\
\hline $13: 42$ & Stop nitrite/sample & 122.2 & 115 & 1.45 & 77.83 & 13.9 & 0.25 & 42.2 & 0.111 & 12.7 & 1.626 & 0.61 & 0.31 \\
\hline $13: 52$ & heat off/ sample & 121.2 & 114 & 1.54 & 77.39 & 13.9 & & & 0.108 & 12.3 & 1.626 & & \\
\hline $14: 35$ & Cooled/Sample & 119.6 & 112 & 1.36 & 77.39 & 13.9 & & & 0.092 & 10.3 & 1.626 & & \\
\hline $4 / 3 / 2007$ & HAW-23b & & & & & & & & & & & & \\
\hline $7: 10$ & Start Hotplate & 115.9 & 102 & & & & & & 0.253 & 25.7 & & & \\
\hline $7: 35$ & 95C sample/Start Nitrite & 115.9 & 102 & 1.27 & 142.23 & & & & 0.257 & 26.2 & & & \\
\hline $7: 56$ & sample & 122.3 & 107 & 1.40 & 134.62 & 6.8 & 0.32 & 20.6 & 0.163 & 17.5 & 0.787 & 0.42 & 0.42 \\
\hline $8: 18$ & Stop nitrite/sample & 128.7 & 113 & 1.65 & 126.85 & 13.7 & 0.31 & 41.6 & 0.046 & 5.1 & 1.590 & 0.59 & 0.51 \\
\hline $8: 28$ & heat off/ sample & 127.0 & 111 & 1.64 & 126.85 & 13.7 & & & & 5.1 & 1.590 & & \\
\hline $10: 50$ & Cooled/Sample & 125.4 & 109 & 0.92 & 126.85 & 13.7 & & & & 5.1 & 1.590 & & \\
\hline $4 / 2 / 2007$ & HAW-23c & & & & & & & & & & & & \\
\hline $12: 35$ & Start Hotplate & 126.7 & 103 & & & & & & 0.252 & 26.0 & & & \\
\hline $12: 58$ & 95C sample/Start Nitrite & 126.7 & 103 & 1.53 & 126.85 & & & & 0.255 & 26.3 & & & \\
\hline $13: 18$ & sample & 132.7 & 108 & 1.51 & 119.33 & 6.7 & 0.33 & 20.3 & 0.144 & 15.6 & 0.773 & 0.53 & 0.53 \\
\hline $13: 42$ & Stop nitrite/sample & 138.9 & 113 & 1.60 & 111.62 & 13.6 & 0.29 & 41.2 & 0.006 & 0.6 & 1.566 & 0.72 & 0.62 \\
\hline $13: 52$ & heat off/ sample & 137.3 & 112 & 1.30 & 111.62 & 13.6 & & & & 0.6 & 1.566 & & \\
\hline $14: 35$ & Cooled/Sample & 136.0 & 112 & 1.67 & 111.62 & 13.6 & & & & 0.6 & 1.566 & & \\
\hline
\end{tabular}


Table VII. Nitrate and Sulfate Material Balances.

\begin{tabular}{|c|c|c|c|c|c|c|c|c|}
\hline & & $\begin{array}{l}\text { Pot } \\
\mathrm{mL}\end{array}$ & $\begin{array}{l}\text { Nitrite* } \\
\text { mmol }\end{array}$ & $\begin{array}{c}\mathrm{NO}_{3}^{-} \\
\mathrm{M} \\
\end{array}$ & $\begin{array}{c}\mathrm{SO}_{4}{ }^{2-} \\
\mathrm{M} \\
\end{array}$ & $\begin{array}{l}\mathrm{NO}_{3}^{-} \\
\mathrm{mmol} \\
\end{array}$ & $\begin{array}{l}\mathrm{SO}_{4}{ }^{2-} \\
\mathrm{mmol}\end{array}$ & $\begin{array}{l}\mathrm{NO}_{3}{ }^{-} \text {produced/ } \\
\mathrm{NO}_{2}{ }^{-} \text {added } \%\end{array}$ \\
\hline $3 / 27 / 2007$ & HAW-22d & & & & & & & \\
\hline $9: 17$ & Start Hotplate & 100 & & 0.001 & 3.50 & 0.143 & 349 & \\
\hline $9: 47$ & 95C sample/Start Nitrite & 98 & & 0.002 & 3.65 & 0.240 & 357 & \\
\hline 10:09 & sample & 103 & 25.3 & 0.044 & 3.36 & 4.53 & 347 & $17 \%$ \\
\hline $10: 30$ & Stop nitrite/sample & 106 & 44.0 & 0.085 & 3.17 & 9.01 & 336 & $20 \%$ \\
\hline $10: 41$ & heat off/ sample & 104 & & 0.087 & 3.17 & 9.06 & 331 & \\
\hline 13:07 & Cooled/Sample & 101 & & 0.099 & 3.24 & 10.03 & 329 & \\
\hline $3 / 29 / 2007$ & HAW-22e & & & & & & & \\
\hline $7: 48$ & Start Hotplate & 103 & & 0.001 & 3.50 & 0.148 & 360 & \\
\hline $8: 15$ & 95C sample/Start Nitrite & 103 & & 0.053 & 4.03 & 5.436 & 414 & \\
\hline $10: 45$ & sample & 108 & 23.0 & 0.085 & 3.76 & 9.25 & 407 & $17 \%$ \\
\hline $13: 20$ & Stop nitrite/sample & 114 & 46.4 & 0.154 & 3.48 & 17.59 & 397 & $26 \%$ \\
\hline $13: 33$ & heat off/ sample & 113 & & & & & & \\
\hline $14: 29$ & Cooled/Sample & 109 & & & & & & \\
\hline $3 / 30 / 2007$ & HAW-22f & & & & & & & \\
\hline $12: 50$ & Start Hotplate & 103 & & 0.001 & 3.50 & 0.148 & 362 & \\
\hline $13: 14$ & 95C sample/Start Nitrite & 103 & & 0.005 & 4.04 & 0.507 & 418 & \\
\hline $13: 19$ & sample & 110 & 25.6 & 0.052 & 3.81 & 5.69 & 418 & $20 \%$ \\
\hline $13: 24$ & Stop nitrite/sample & 111 & 34.5 & 0.090 & 3.66 & 10.05 & 407 & $28 \%$ \\
\hline $13: 35$ & heat off/ sample & 110 & & & & & & \\
\hline $13: 47$ & Cooled/Sample & 102 & & & & & & \\
\hline $6 / 25 / 2007$ & HAW-22fa & & & & & & & \\
\hline $12: 47$ & Start Hotplate & 99 & & 0.001 & 3.50 & 0.142 & 346 & \\
\hline $13: 15$ & 95C sample/Start Nitrite & 99 & & 0.002 & 3.92 & 0.160 & 388 & \\
\hline $13: 19$ & sample & 108 & 34.0 & 0.062 & 3.68 & 6.74 & 398 & $19 \%$ \\
\hline $13: 24$ & Stop nitrite/sample & 111 & 47.7 & 0.101 & 3.56 & 11.31 & 397 & $23 \%$ \\
\hline $13: 34$ & heat off/ sample & 111 & & 0.091 & 3.57 & 10.03 & 395 & \\
\hline $14: 50$ & Cooled/Sample & 106 & & 0.110 & 3.56 & 11.76 & 379 & \\
\hline $6 / 26 / 2007$ & HAW-23aa & & & & & & & \\
\hline $13: 55$ & Start Hotplate & 102 & & 2.003 & 0.125 & 204.1 & 13 & \\
\hline $14: 15$ & 95C sample/Start Nitrite & 102 & & 1.839 & 0.119 & 187.3 & 12 & \\
\hline $14: 36$ & sample & 109 & 21.8 & 1.790 & 0.113 & 194.7 & 12 & $34 \%$ \\
\hline $14: 57$ & Stop nitrite/sample & 115 & 42.6 & 1.774 & 0.108 & 204.1 & 12 & $39 \%$ \\
\hline $15: 07$ & heat off/ sample & 114 & & 1.758 & 0.108 & 200.3 & 12 & \\
\hline $6: 50$ & Cooled/Sample & 113 & & 1.758 & 0.108 & 198.5 & 12 & \\
\hline
\end{tabular}

* Nitrite totals are cumulative mmol added. 